\title{
Katalánská kartografická díla 14. a 15. století a zachycení Asie a Afriky
}

\author{
Vladimír Liščák \\ Oddělení východní Asie, Orientální ústav Akademie věd České republiky, Pod Vodárenskou věží 4, 18208 Praha 8
}

Do redakce doručeno 7. dubna 2017; k publikaci přijato 3. listopadu 2017

Tento článek vychází s podporou MOFA Taiwan Fellowship (外交部「臺灣獎助金」) 2016

This article was kindly supported by MOFA Taiwan Fellowship (外交部「臺灣獎助金」) 2016

\section{CATALAN CARTOGRAPHIC WORKS OF THE $14^{\mathrm{TH}}$ AND $15^{\mathrm{TH}}$ CENTURIES AND THE MAPPING OF ASIA AND AFRICA}

\begin{abstract}
Urs Graf Verlag GmbH Publishing House in Dietikon (Zürich metropolitan area, Switzerland) has published, in 1977 and 1995 , facsimiles-replicas of two outstanding Catalan cartographic works of the fourteenth and fifteenth centuries. First of them was the Mappa mundi of 1375 (it was drawn between 1375 and 1381), second was the circular Catalan-Estense map (Mappa mundi Estense) drawn somewhen between 1450 and 1460. The first work is known also as the Catalan Atlas, because it is composed of several tables sketching out the world known at that time, from the Atlantic Coast of Europe to the Pacific Coast of East Asia. The main sources for the eastern parts of the world were travelogues of Marco Polo, Sir John Mandeville and Odoric of Pordenone. (Grosjean, ed. 1977) The second of these two replicas is the circular map with the average of 113 centimetres, including not only the known world but also countries supposed, still undiscovered, with their approximate location. (Milano, ed. 1995) Both of these works are richly illustrated with many pictures of persons, creatures and also flags. Replicas of these cartographic works are in original size and are accompanied with detailed essays and transcriptions of Latin and Catalan texts with their annotated translations into German (Catalan Atlas) and Italian and German (Mappa mundi Estense). This article gives an overview of these two maps with original texts and their translations based on the latest literature.
\end{abstract}

KEY WORDS medieval maps of the world; Mallorcan cartographic school; Catalan Atlas; Mappa mundi Estense

ABSTRAKT Švýcarské nakladatelství Urs Graf Verlag GmbH se sídlem v Dietikonu na předměstí Curychu vydalo v letech 1977 a 1995 faksimile dvou výjimečných katalánských kartografických děl 14. a 15. století. Prvním z nich byla Mappa mundi, jež vznikla mezi lety 1375 a 1381), druhým kruhová Mappa mundi Estense z období mezi 1450 a 1460. První dílo je označováno též jako Katalánský atlas 1375 a skládá se z několika tabulí zachycujících tehdy známý svět od pobřeží Atlantského oceánu až po východní pobřeží Asie. Hlavními prameny pro zpracování východní části Asie byly cestopisy Marka Pola, tzv. Jana Mandevila a Odorika z Pordenone. (Grosjean, ed. 1977) Druhým dílem je kruhová mapa o průměru $113 \mathrm{~cm}$, zachycující kromě známého světa i země dosud neobjevené, ale předpokládané, s jejich přibližnou polohou. (Milano, ed. 1995) Obě díla jsou bohatě ilustrována a na své si přijdou i milovníci vlajek. Faksimile, reprodukující díla ve skutečné velikosti, doplňují podrobné studie a přepisy katalánských textů na mapách s jejich komentovanými překlady (v prvním př́padě do němčiny, ve druhém do italštiny a němčiny). Tento př́spěvek podává přehled o obou těchto mapách s originálními texty a jejich překlady na základě nejnovější literatury.

KLÍČOVÁ SLOVA středověké mapy světa; mallorská kartografická škola; Katalánský atlas; mapa z Estense

\section{TRADICE PORTOLÁNOVÝCH MAP}

Jak Katalánský atlas, tak Mappa mundi Estense vychází částečně z tradice portolánových map čili map pro orientaci námořníků. Portolánové mapy jsou italského původu a představovaly v té době zcela nový typ středověké kartografické produkce. Název pochází z italského výrazu portolani (z latinského portus, prrístav), což byly prríručky pro navigaci mezi 


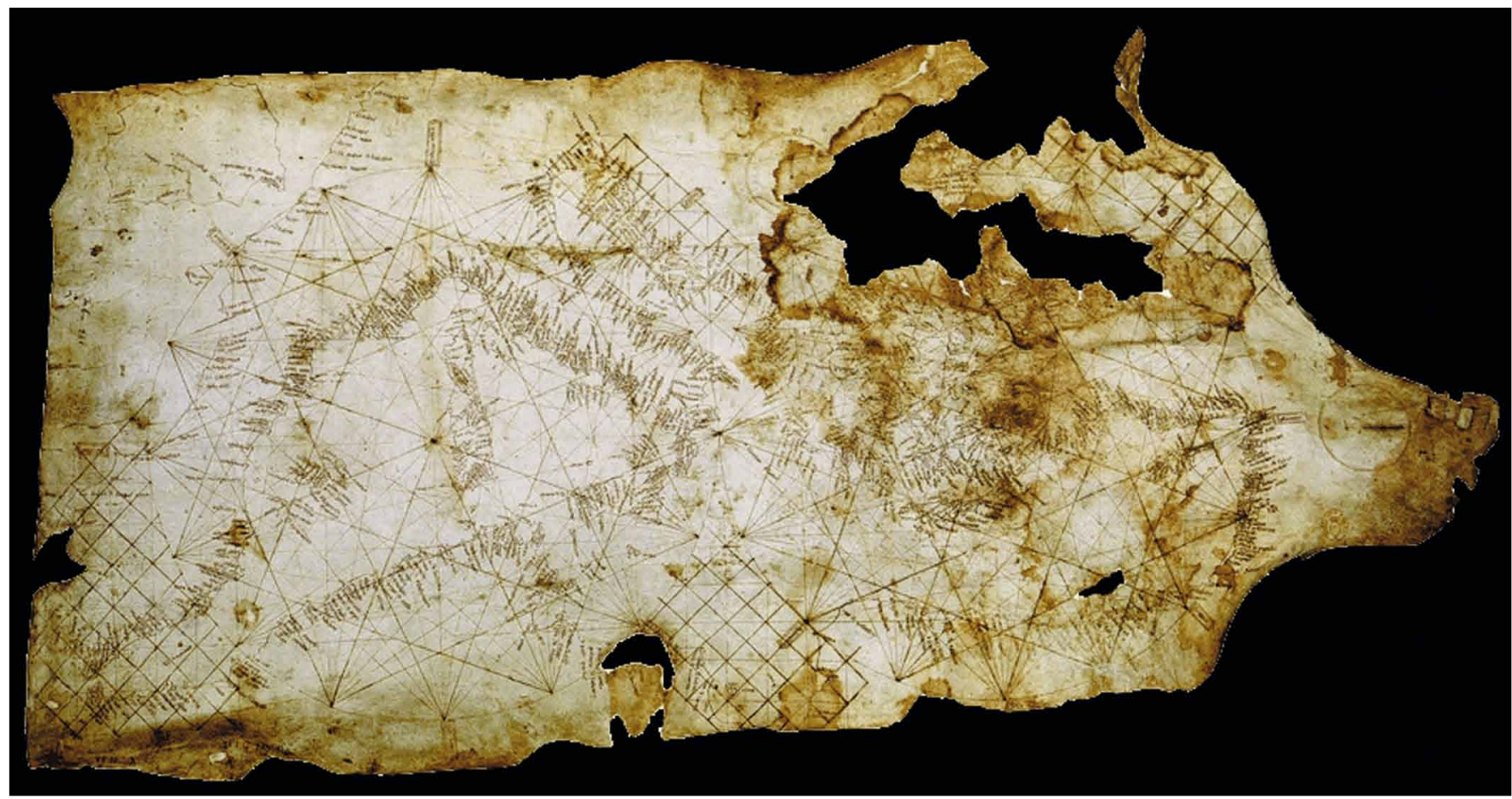

Obr. 1. Nejstarší dochovaná portolánová mapa je tzv. pisánská mapa (Carta Pisana) z doby po roce 1275. (zdroj: https://commons.wikimedia.org/wiki/File:Carta_Pisana.png)

přistavy. Zakreslovaly hlavně mořské pobřeži (zprvu Středozemního moře, západní a severní Evropy) se všemi př́stavy, zálivy a zátokami.

Nejstarší portolánové mapy, které se dochovaly, jsou italského původu - byly zhotoveny v Janově a Pise. Autory portolánových map, jež vznikly ve druhé polovině 14 . století, jsou zejména Katalánci. Avšak typické katalánské mapy nejsou vlastně portolánovými mapami. Jsou něčím víc. Zatímco portolano je $\mathrm{v}$ podstatě námořní příručkou zaměřenou na navigaci podél pobřeží, katalánská mapa je ve skutečnosti mapou světa nakreslenou kolem portolánové mapy. Portolánové mapy se používaly např. pro Středozemní moře, Černé moře či Rudé moře. ${ }^{2}$

Geografickou sít tyto mapy zprvu neměly, zato byly opatřeny svazkem paprsků vycházejících ze společného středu, později kompasovými růžicemi. Ve středu mapy bývala nakreslena alespoň jedna ústřední růžice o 16 paprscích a kolem ní zpravidla dalších 16 růžic o dvojnásobném počtu paprsků, celkem tedy 32 směrů po $11,25^{\circ}$. Tato osnova poskytovala plavcům dostatek údajů o směrech. Předpokládala ovšem používání kompasu při námořní plavbě. Tento systém se stal základem pro kompasové růžice, zobrazené na pozdějších mapách, poprvé u Katalánského atlasu 1375.

1 Je zajímavé, že portolani nezůstaly jen středověkou záležitostí Současné milánské nakladatelství Edizioni Il Frangente Sas di Luisa Bresciani e C. vydává mimo jiné i moderní portolani (zejména série I portolani del Mediterraneo, ale i jiné části světa). <http://www.frangente.com/ilfrangente/5-cat-Mediterraneo.htm >

2 Portolani nebraly v úvahu zakřivení země, v důsledku toho byly neužitečné jako navigační nástroje při plavbě po oceánu.
Výroba portolánových map, kreslených na pergamenu, se ve Středomoří soustředovala jednak do Itálie (Benátky, Janov, Ankona), jednak to Katalánska (Mallorca a Barcelona). Italské portolány se obyčejně omezují na břehy Stř̌edomoří a západoevropské pobřeží, katalánské sahají na severu až do Skandinávie a na východ někdy až do Číny, takže jsou vlastně mapami světa (mappce mundi). Katalánské námořní mapy si také daleko více všímají vnitrozemského místopisu, např. stř̌edoevropského a východoevropského, poněvadž Aragonci tenkrát obchodovali na Černém moři, Volze i Baltu.

Nejstarší dochovaná portolánová mapa je tzv. pisánská mapa (Carta Pisana) z doby po roce 1275 , snad kopie starší práce. ${ }^{3}$ Dřive patřila jedné rodině $\mathrm{v}$ Pise (odtud pochází její označení), dnes je uložena v Národní knihovně v Pařízii. ${ }^{4}$ Texty na této mapě jsou v několika jazycích, což není neobvyklé v té době. To je jeden $\mathrm{z}$ důvodů, proč je obtí̌né určit původ mnoha portolánových map. (Campbell 1987, 388-389, 404)

Nejstarší signovaná a datovaná portolánová mapa, která se ze středověku dochovala, je z roku 1311 (C.N.1, Archivio di Stato ve Florencii, Itálie). (Edson 2004, 137) Jejích tvưrcem je Janovan Pietro (Petrus) Vesconte (či Visconte, působil 13101330), mimo jiné i autor prvního námořního atlasu z roku

3 Různé prameny uvádějí, že vznikla „,asi 1275“ nebo „asi 1290“, tedy ne dříve než v roce 1275. (Campbell 1987, 404)

41 pergamenový list, $500 \times 1050 \mathrm{~mm}$. Paris, Bibliothèque nationale de France, Département des cartes et plans, Rés. Ge. B1118. Analýzu Carty Pisany viz online $<\mathrm{https}$ ///sinsemia.files.wordpress. com/2011/04/vitanova_2_cartapisana.pdf $>$. 


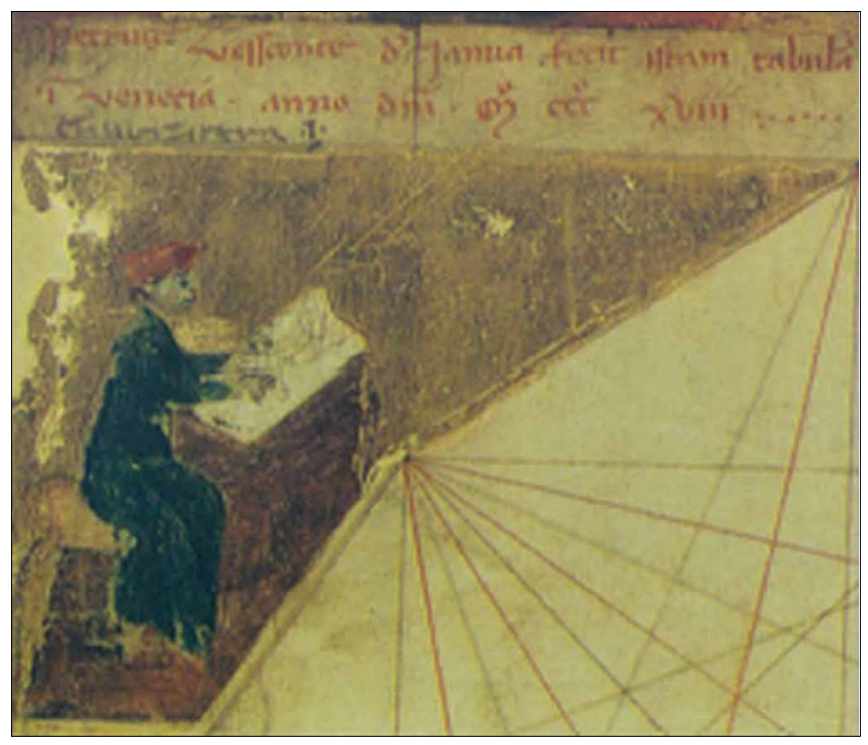

Obr. 2. Pravděpodobně podobizna Pietra Vesconta na jedné $\mathrm{z}$ jeho map s popiskou „Petrus Vesconte de Janua fecit istam tabula in Venecia anno dñi $\mathrm{m}^{\circ} \mathrm{ccc}^{\circ}$ xviii“ [Pietro Vesconte $\mathrm{z}$ Janova zhotovil tuto mapu v Benátkách L. P. 1318]. (zdroj: Civico Museo Correr, Benátky (Collezione Correr, Port. 28, fol. 2) - viz Cambell 1987, nestr. příloha, tab. 31)

$1313^{5}$, kruhové mapy světa z roku 1320 a dalších kartografických děl. Přestože se Vesconte narodil v Janově, hodně z jeho prací vzniklo v Benátkách. Jeho Mappa Mundi (asi 1320) o průměru 35 centimetrů, je spolu s dalšími nepodepsanými a nedatovanými mapami součástí rukopisu Marina Sanuta (Marino detto Torsello sen Sanuto, latinsky Marinus Sanutus senex, dictus Torsellus, asi 1260-1338) ${ }^{6}$ Liber secretorum fidelium crucis super Terre Sancto recuperatione et conservatione (známého též jako Secreta fidelium Crucis či Liber de expeditione Terree Sanctce nebo Opus Terre Sanctoe), datovaného mezi 1306 a 1321. (Kunstmann 1855)

\section{KATALÁNSKÁ (MALLORSKÁ) KARTOGRAFICKÁ ŠKOLA}

Přibližně ve stejné době jako italské portolánové mapy začaly vznikat mapy katalánské kartografické školy, jejímž centrem byl ostrov Mallorca, součást Baleárských ostrovů (katalánsky Illes Balears, španělsky Islas Baleares). Jejich metropolí je Palma (de Mallorca) ${ }^{7}$, dříve známá též jako Ciutat de Mallorca.

V roce 1137 Aragonské království (aragonsky Reino d’A-

56 iluminovaných pergamenových listů, 480 x $400 \mathrm{~mm}$. Paris, Bibliothèque nationale de France, Département des cartes et plans, Rés. Ge. DD687.

6 Marino Sanuto byl benátský státník a geograf. Pietro Vesconte nakreslil pro něj několik atlasů.

7 Katalánský oficiální název často vynechává přívlastek „de Mallorca“. Přehled změn v oficiálním názvu viz např. https://ca.wikipedia.org/wiki/Palma. ragón, katalánsky Regne d’Aragó, latinsky Regnum Aragonum) začlenilo pod svou správu Barcelonské hrabství (katalánsky Comtat de Barcelona, latinsky Comitatus Barcinonensis), jedno z katalánských hrabství, která byla částečně sjednocena roku 1162 pod vládou barcelonského hraběte jako Katalánské knížectví (katalánsky Principat de Catalunya, latinsky Principatus Cathalonioe). Katalánsko bylo obchodním partnerem severní Afriky, kde měla tvorba map silnou tradici. Sjednocené království Aragonie a Katalánska bylo od roku 1162 historicky známo jako Aragonská koruna (aragonsky Corona d'Aragón, katalánsky Corona d'Aragó, latinsky Corona Aragonum). Poslední den roku 1229 dobylo na muslimech, vedených almohádovským ${ }^{8}$ guvernérem (wāli) Abú Jahjou (Abū Yahyà Muhammad ibn 'Alì ibn Abì 'Imrān at-Tinmalālī, zemřel 1229) Mallorku a krátce nato zbytek Baleárských ostrovů, kde bylo o dva roky později založeno vazalské Mallorské království (katalánsky Regne de Mallorca, latinsky Regnum Maioricae, 1231-1715).

Tyto okolnosti byly prŕznivé vzniku důležité a kvetoucí kartografické školy, zejména vzhledem k přispění arabských a židovských učenců a kartografư. Školu charakterizovaly četné, bohatě kolorované ilustrace měst a významných zeměpisných objektů, portréty cizích panovníků, rozsáhlá toponymie apod. Avšak ještě předtím, než na Mallorce vznikla první mapa, katalánský učenec z Mallorky Ramon Llull (též Raimundus či Raymundus Lullus nebo Lullius, zvaný Doctor Illuminatus, Doctor Inspiratus, asi 1232-asi 1315), spisovatel, filosof, teolog a logik, člen Třetího (světského) františkánského řádu ${ }^{9}$, zahrnul námořní mapu mezi nástroje navigace pro její význam srovnatelný s kompasem. Teprve však až v roce 1354 král Petr IV. Aragonský (zvaný Obřadný, katalánsky Pere el Cerimoniós, též el del Punyalet, „s krátkou dýkou“, Pere IV d'Aragó, Pere III de Catalunya-Aragó, aragonsky Pero IV d'Aragón, dito o Ceremonioso, 1319-1387, vládl 1336-1387) nařídil, aby na každé lodi říše byly dvě námořní mapy.

Rozdíl mezi mallorskou a italskou školou je spíše ve stylu než rozsahu. Italské portolánové mapy byly strohé, striktně zaměřené na pobřežní detaily, zčásti nebo úplně bez zakresleného vnitrozemí a většinou postrádaly ilustrace. Mallorský styl, který můžeme rozpoznat již na mapě Angelina Dulcerta z roku 1339 a jenž vyvrcholil Katalánským atlasem 1375, obsahoval mnohem více detailů vnitrozemí a byl bohatě zdoben barevnými ilustracemi, zachycujícími města, pohoř́, řeky a některé miniatury lidí. Tyto mapy obsahovaly rov-

8 Chalífát Almohadů (arabsky al-Muwahhidun, berbersky Imweḥhden, 1121-1269) byla berberská muslimská říše, ovládající severní Afriku a jižní část Pyrenejského poloostrova. Po bitvě u las Navas de Tolosa (1212) se v důsledku reconquisty na Pyrenejském poloostrově i povstání v severní Africe jeho moc oslabovala, až poslední chalífa ovládal pouze hlavní město Marrákeš (arabsky Murrākuš, berbersky Merrakec) v Maroku.

9 Roku 1311 na koncilu ve francouzském Vienne prosadil, aby se na hlavních evropských univerzitách (Bologna, Pařižž, Oxford a Salamanca) a při papežském dvoře zř́idily stolice hebrejštiny, arabštiny a chaldejštiny, a je proto někdy považován za zakladatele západoevropské orientalistiky. 


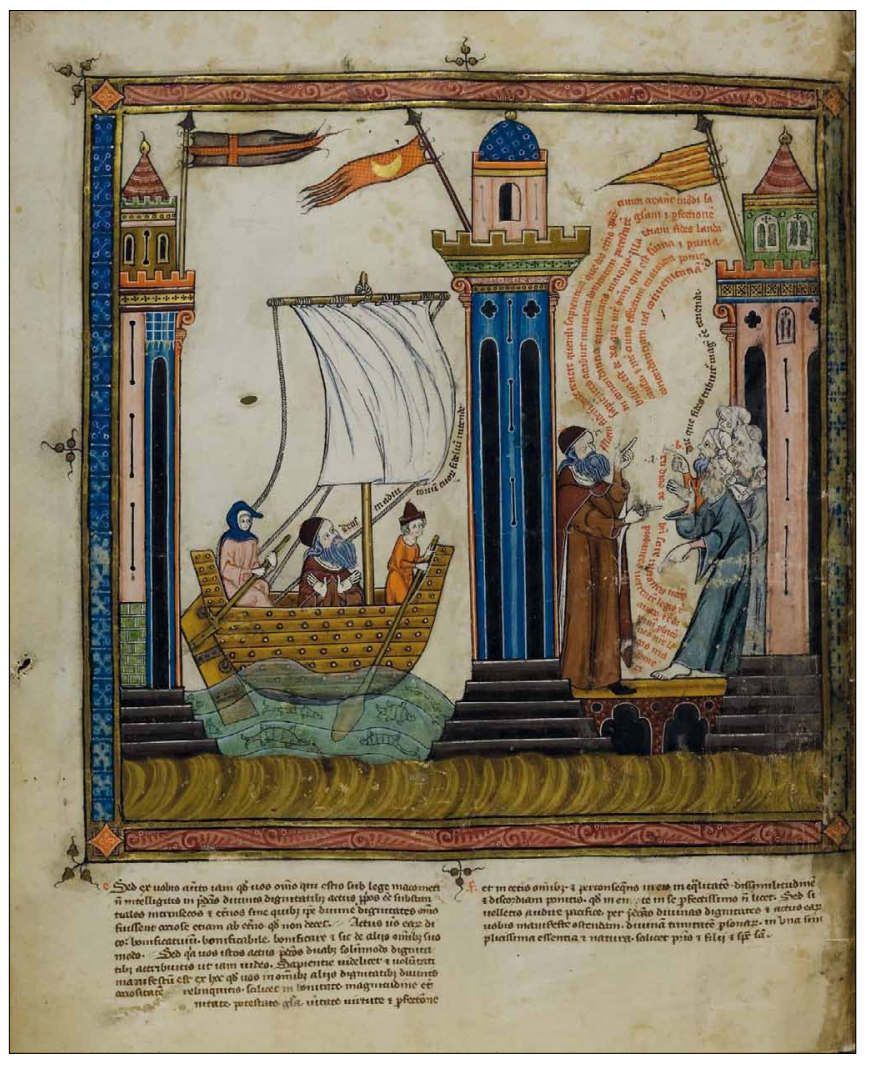

Obr. 3. Ramon Llull je znám z četných vyobrazení v kodexu Breviculum ex artibus Raimundi Lulli electum - Karlsruhe, Badische Landesbibliothek, St. Peter perg. 92 (po roce 1321). Zde je zobrazen na první cestě do Tunisu (f. 9v) <http://digital.blb-karlsruhe.de/blbhs/content/pageview/105558>.

něž popisky a vysvětlující texty v latině a staré katalánštině (catalanesc, romanç).

První mapou, o níž bezpečně víme, že byla vyrobena v Palmě de Mallorca (Ciutat de Mallorca), byla portolánová mapa ${ }^{10}$ nakreslená roku 1339 italsko-mallorským kartografem Angelinem Dulcertem (působil v první polovině 14. století). ${ }^{11}$ Kromě Středomoří zachycovala i severní Evropu a obsahovala též informace o Africe. Stala se prototypem katalánských map

102 iluminované pergamenové listy sestavené do mapy, $750 \mathrm{x}$ $1020 \mathrm{~mm}$. Paris, Bibliothèque nationale de France, Département des cartes et plans, Rés Ge. B696.

11 O Dulcertově původu nevíme téměř nic. Běžně se předpokládá, že pocházel z Ligurie, učil se v Janově a nakonec někdy ve dvacátých či třicátých letech 14. století emigroval na Mallorku. (Crone 1962) Pravděpodobně je to táž osoba jako Angelino Dalorto (též Dalorco, Dall'Orto) (Oldham 1925; Pelletier 1994), jeho skutečným jménem bylo pravděpodobně Angelino de Dulceto či Dulceti (Pujades i Bataller 2007, 491; Llompart i Moragues - Pujades i Bataller - Samsó Moya, eds. 2008: 26) nebo snad Angelí Dolcet. Angelino „Dalorto“ je znám portolánovou mapou běžně datovanou do roku 1325 (později revidováno na 1330), uloženou ve sbírce Corsini ve Florencii. Jeho podpis se tradičně četl jak "Hoc opus fecit Angelinus de Dalorto ano dñi MCCCXXV de mense martii composuit hoc" (a po revizi jako "Angellinus de Dulceto" a „ano dñi MCCCXXX“). (Pujades i Bataller 2007, 491; Amat di S. Filippo 1888, 273; Carreras y Candi 1919, 55) kreslených ve 14. a 15. století: živé barvy, názvy míst, topografické detaily, stejně jako legendy a vysvětlivky (zde psané latinsky) - to vše obvykle chybělo na dosavadních janovských a benátských portolánových mapách. Kromě toho je zde již zřejmý odklon od „středomořského“ rámce starších portolánových map, nebot tato mapa zahrnuje i severní Evropu a více informací o Africe. (Oldham 1925) ${ }^{12}$

Katalánský atlas 1375 vykazuje důležité podobnosti s Dulcertovou portolánovou mapu, pokud jde o kresbu její západní část, doplněnou o velký počet vysvětlivek. Jeho originalita však spočívá $\mathrm{v}$ přidání východní poloviny, která nevycházela ze zkušeností stř̌edomořských námořníků, jak tomu bylo u portolánových map, nýbrž využívala různé prameny, včetně zpráv Marka Pola a Odorika z Pordenone.

Jiným zajímavým př́ikladem mapového díla Mallorské kartografické školy je portolánová mapa, kterou roku 1413 nakreslil Mecia (Macià) de Viladestes, pravděpodobně pokřtěný mallorský Žid. ${ }^{13}$ Jeho dílo v mnohém vychází z Katalánského atlasu, přičemž značnou pozornost věnuje Africe a transsaharské obchodní cestě do Timbuktu. ${ }^{14}$. Mallorská kartografická škola významně změnila způsob tvorby námořních i pozemních map: katalánští kartografové obratně začleňovali do svých map čerstvé informace, a tak měnili tradiční rámec mapových děl.

\section{KATALÁNSKÝ ATLAS 1375 A JEHO ZHOTOVITELÉ}

Kolem roku 1375 vzniklo mistrovské dílo mallorské kartografické školy 14 . století, které je považováno za jedno z nejlepších děl středověké kartografie, prredstavující tehdy nejdokonalejší mapu známého světa. Protože ho tvoří šest samostatných listů, začalo se mu později říkat Katalánský atlas. (Paris, Bibliothèque nationale française, Richelieu Manuscrits Espagnol 30) Jako první atlas vůbec znázornil také větrnou růžici. Autorství je přisuzováno, ač bez naprosté jistoty, katalánské škole Cresquese Abrahama. Nejpravděpodobněji byl vytvořen v roce 1375 či krátce po něm, protože toto datum se objevuje na věčném kalendáři spolu s mapami.

12 Mimo jiné poprvé zaznamenává jméno ostrova Lanzarote, jednoho z Kanárských ostrovů, jako Insula de Lanzarotus Marocelus, což je odkazem na janovského mořeplavce Lancelotta Malocella (latinsky Lanzarotus Marocelus, kolem 1312), jemuž se připisuje znovuobjevení Kanárských ostrovů v roce 1312. (Licata 2012)

131 iluminovaný pergamenový list, 850 x $1150 \mathrm{~mm}$. Paris, Bibliothèque nationale de France, Département des cartes et plans, Rés. Ge. AA566.

14 Timbuktu je tuarežské město $\mathrm{v}$ dnešním státě Mali v západní Africe. Založeno bylo patrně již v 10. století, kdy zde byla obchodní stanice. Město leželo na významné obchodní stezce, vedoucí z jihu na sever např́č Saharou. Kromě obchodu s otroky, zlatem, slonovinou, solí a dalším zbožím se ve 14. století také stalo významným centrem západoafrické vzdělanosti. V té době zde žilo 100 až 200 tisíc lidí, z nichž asi čtvrtinu tvořili učenci. 
Cresques Abraham (11. července 1325-březen 1387) ${ }^{15}$ byl katalánský židovský kartograf a pravděpodobně tento atlas vytvořil ve spolupráci se svým synem Jehudou (1350/13601410), známým též jako Jafudà Cresques, Jaume Riba (po pokřtění). Po mnoho let pưsobil na dvoře aragonského krále jako „mistr mappce mundi a kompasü“ (latinsky magister mappamundorum et bruxolarum, ve staré katalánštině maestre de mapa mundi e de buxolas). Cresques věnoval svůj život tvorbě map, konstrukci hodin, kompasů a dalších typů námořních př́istrojů až do roku 1375, kdy se synem obdržel pověření od prince Jana Aragonského (1350-1396, pozdějšího krále Jana I., katalánsky Joan I d'Aragó, Joan I de Catalunya-Aragó, aragonsky Chuan I d'Aragón, řečeného "Lovec“, katalánsky el Caçador, aragonsky lo Cazataire, též zvaného „Milovník elegance“, katalánsky l’Amador de la Gentilesa, aragonsky o Amador d’a Chentileza, či „Opuštěný“, katalánsky el Descurat, vládl 1387-1396) s úkolem vytvořit úplnou sérii námořních map, která bude prezentovat prakticky celý tehdy známý svět. Za tento úkol Cresques a jeho syn Jehuda dostali, podle dochovaných dokumentů, od Jana Aragonského zaplaceno 150 aragonských zlatých florénů (florins d'or d'Aragó) a 60 mallorských liber (lliures mallorquines).

Z výzkumů posledních padesáti let vyplývá, že Cresques byl spolehlivě identifikován s Elišou, synem rabiho Abraháma, syna rabiho Benavisty, syna rabiho Eliši, zvaným Cresques (Eliša be-rabbi Abraham be-rabbi Benveniste be-rabbi Eliša, ha-mekuneh Qresque), který iluminoval Bibli Farhi (MS 368) nalezenou roku 1966 ve sbírce Sassoon v Letchworth, Hertfordshire (England). (Rabinowicz 1966, 136; Kogman-Appel 2015) Podle kolofonu umístěném $\mathrm{v}$ této Bibli se narodil v městě Ciutat de Mallorca 28. tamuze 5085 (= 11. července 1325). (Casar 2008, 25; Riera i Sans 1975; Nogueira 2013, 139) $\mathrm{Na}$ knize začal pracovat roku 1366 ve věku 41 let a dokončil ji ve středu 13. kisleva 5143 (=19. listopadu 1382). (Rabinowicz 1966, 136; Kogman-Appel 2014, 34)

Předpoklad, že autorem Katalánského atlasu je Cresques, vychází ze skutečnosti, že v listopadu 1381 zmíněný princ Jan Aragonský, vévoda z Girony, prvorozený syn Petra IV. Aragonského a pozdější král Jan I., chtěl obdarovat Karla VI. Šíleného (Charles VI le Fou, původně zvaný „Milovaný“, le BienAimé, 1368-1422, vládl 1380-1422), nového krále Francie, a rozhodl se mu poslat mapu světa, kterou vlastnil a jež byla uložena v archívu v Barceloně. Nařídil proto nalézt jejího autora Cresquese Žida („Cresques lo juheu qui lodit mapamundi a fet"), aby mapu mohl zkopírovat. Není známo, jestli k tomuto obdarování skutečně došlo, protože, pokud víme, jeden exemplář atlasu byl v královské knihovně v Pařiži již ke konci roku 1380. (Grosjean, ed. 1977, 12-13)

Nicméně víme, že Cresques byl autorem celé řady námořních map, které tvořil pro aragonské panovníky (připisuje se mu na 21 děl). Se svou manželkou Settadar (po jeho

15 Jeho jméno najdeme často v podobě Abraham Cresques, avšak „Cresques“ není jeho př́ijmení. Jeho jméno znamená „Cresques [syn] Abrahamův“. Stejně tak jméno jeho syna znamená „Jehuda [syn] Cresquesův“. - Viz Grosjean, ed. (1977): 12-13. smrti konvertovala a přijala křestanské jméno Anna) (Kogman-Appel 2015, 171) obýval velký dům v židovské čtvrti v dnešní Palma de Mallorca. V roce 1368 mu byl přiznán titul "familiaridad real“ (královský důvěrník), což podtrhovalo zvláštní př́izeň královského dvora a neslo s sebou různá privilegia.

Jeho syn Jehuda (Jafudà, kolem 1350-1410 nebo 1427) spolupracoval s otcem možná již na tomto atlase, $\mathrm{v}$ každém př́ípadě se jeho spolupracovníkem stal nejpozději roku 1382. V důsledku aragonského pronásledování Židů v roce 1391 konvertoval a přijal jméno Jaume Riba. V roce 1419 Jindřich Mořeplavec (Infante Dom Henrique, zvaný Navegador, 13941460), druhý syn portugalského krále Jana I. (João I, 13571433, vládl 1385-1433), zrrídil námořní školu v Sagres a povolal jistého Mestre Jacome de Malhorca jako kartografického koordinátora. Řada vědců se domnívá, že tímto Jacomem byl Jehuda Cresques (nyní Jaume Riba). ${ }^{16}$ (Grosjean, ed. 1977, 13) Katalánský atlas se nejpozději od roku 1411 skládal ze šesti pergamenových listů umístěných na šest velkých dřevěných desek. Každý list měřil přibližně 65 x $50 \mathrm{~cm}$. Za Ludvíka XII. Otce lidu (Louis XII le Père du Peuple, 1462-1515, vládl 1498$1515)$ byla každá $z$ desek rozdělena na dvě poloviny a pergamenové listy nalepeny na obě strany sedmi tabulí. Vzniklo tak leporelo s listy o velikosti 64,3 x $24,9 \mathrm{~cm}$, přičemž celkové rozměry včetně úvodních tabulí jsou přibližně $65 \mathrm{x} 300 \mathrm{~cm}$. Atlas nemá přesně danou orientaci (sever nahoře nebo dole), nebot popisky jsou různě umístěny tak, že se jednou dají číst ze severu, jindy $\mathrm{z}$ jihu. Je to evidentně dáno velkými rozměry atlasu, takže bylo pohodlné atlas ležící na stole obcházet a číst bližší popisky. Dnešní uspořádání pochází z doby krátce po roce 1500: jižní orientace $\mathrm{v}$ pořadí listů I-II-VI-V-IV-III, nicméně bibliofilská vydání se řídí původním uspořádáním v severní orientaci s pořadím listů I až VI (podle dnešních zvyklostí i podle zvyklostí běžných portolánových map). (Grosjean, ed. 1977, 11)

Atlas je datován rokem 1375 - toto datum se objevuje na věčném kalendáři vyobrazeném na listě Ia a je zmíněno i na listě IIa. ${ }^{17}$ Již v roce 1380 se objevuje v inventáři knihovny francouzského krále Karla V. Moudrého (Charles V le Sage, 13381380, vládl 1364-1380), sepsaném královým tajemníkem Jea-

16 Citují se zejména: Duarte Pacheco Pereira (zemřel 1533): „... isso mesmo mandou á ilha de Malhorca por um mestre Jacome, mestre de cartas de marear, na qual ilha primeiramente se fezeram as ditas cartas, e com muitas dadiuas e mercês ho ouue nestes rreynos, ho qual as ensinou a fazer áquelles de que os que em nosso tempo viuem, aprenderam“ a João de Barros (1496-1570): „...mándou vir da ilha de Malhórca hũ mestre Jacome, hómẽ muy docto na árte de nauegár, que fazia cártas \& instrumentos [náuticos]: o qual lhe custou muyto polo trazer a este reino, pera ensinar sua sciẽcia aos officiáes portugueses daquelle mistér." - Almeida - Costa Brochado - Dias Dinis, eds. (1963): 159, pozn. 1.

17 „E ayxi hoc sapiats que en l'any.M.CCCLXXV. corra l'auro nomero en .VIII.“; „E sepiatz de sert que l'ayn .M.CCCLXXV. corra l'auru nonro en .VIII. ... " [...Vězte, že zajisté rok 1375 nese zlaté číslo 8...] - překlad a přepis podle Grosjean, ed. (1977), 38 a 52; Nogueira (2013), 267 a 283; Buchon - Tastu (1839), 26 a 30. 
nem Blanchetem (Jehan Blanchet, secretaire du Roy) po smrti panovníka (zemřel v záŕí 1380). Tento inventář (datovaný 6 . listopadu 1380) je opisem dnes ztraceného katalogu královského knihovníka Gillesa (či Gileta) Maleta (zemřel 1411) z roku 1373 doplněným o př́růstky. Atlas je zde uveden pod číslem 201: „Une carte de mer en tabliaux faicte par manière de unes tables, painte et historiée, figurée et escripte. " [Námořní mapa ve více listech, zhotovená v podobě jednotlivých tabulí, malovaná a opatřená historickými poznámkami, s vyobrazeními a popiskami.] V jiném opise katalogu Gillesa Maleta je atlas uveden pod číslem 200: „Une quarte en tabliaux faiz par manière et [de] une[s] tables ystoriee, figuree et escripte et fermant a IIII fermoir“ [Mapa ve více listech, zhotovená v podobě jednotlivých tabulí, opatřená historickými poznámkami, s vyobrazeními a popiskami a uzavřená do čtyř rámů.] (Grosjean, ed. 1977, 9)

Po smrti Gillesa Maleta v roce 1411 byl pořízen nový inventář, který Katalánský atlas popisuje již podrobněji: „Item une quarte de mer, en tableaux, faicte per manière de unes tables, painte et historiee, figurée et escripte à quatre fermouers de cuivre, laquele quarte contient six grans feuillez qui sont de bois, sur lesquels fueillez est colé le parchemin, ouquel sont faictes les dites figures, couvert de cuir blanc a deux rondeaux ouvrez." (Palomo 2002, 6; Buchon - Tastu 1839, 3)

\section{OBSAH KATALÁNSKÉHO ATLASU}

Prezentace Asie byla jedním z největších přínosů Katalánského atlasu, $\mathrm{v}$ němž tento kontinent poprvé v historii získal alespoň přibližný tvar. Díky tomu, že kartografové použili $\mathrm{k}$ úpravě tradičního obrazu světa ty nejspolehlivější informace, zejména z cestopisů Marka Pola a Odorika z Pordenone, ale i tzv. Jana Mandevily a zřejmě i arabských zpráv, byla z map eliminována většina tradičních chyb, které byly přijímány po staletí.

Titul (či přesněji začátek textu) Katalánského atlasu jasně ukazuje, v jakém duchu byl realizován: Mapa mondi vol dir aytant con ymage del món e de les diverses etats del món e de les regions que són sus la terra de diverses maneres de gen qui en ela habiten [Mapa světa, to jest obraz světa a oblastí, jež jsou na zemi a rozličných národi̊, jež ji obývají]. (Grosjean, ed. 1977, 41; Nogueira 2013, 269; Buchon - Tastu 1839, 4) Na rozdíl od většiny katalánských map té doby nemá kruhovou podobu, ale obdélníkovou. Princ Jan jako zadavatel díla se pravděpodobně nezajímal ani o severní části Evropy, ani o jižnější oblasti Afriky, ale spíše o Orient a Západní oceán. Kartograf ho uspokojil tím, že provedl výřez požadované části z kruhové mapy světa. Pozdější katalánské mapy, jako např. Mappa mundi Estense (mezi 1450 a 1460), mají opět kruhový tvar.

Katalánský atlas se skládá ze tř́i zcela odlišných částí. Nejdůležitější částí jsou tabule III a IV, tedy kopie portolánové mapy Středomoří a okolí. Známkou portolánových map je ohromující přesnost celkových proporcí a průběhu pobřeží a velké množství místních jmen. Jenom na severním pobřeží
Stř̀edozemního moře bylo napočítáno 620 jmen, celkem tato mapa obsahuje na 1120 jmen v pobřežních oblastech, což je téměř polovina z 2300 jmen celého atlasu. Tato část zahrnuje všechny země v Evropě a Středomoří (včetně severní Afriky), známé ve 14 . století (mezi $20^{\circ}$ a $60^{\circ}$ severní šiŕrky).

Poprvé se zde objevuje větrná růžice, sama umělecké dílo (tabule III). Obsahuje 32 směrů (po 11,25) a vyznačení 8 větrů zastupujících hlavní a vedlejší světové strany - toto rozdělení na osm dílů pochází $\mathrm{z}$ antiky (na mapě jsou jejich názvy ve staré italštině): Tramuntana ${ }^{18}$ (sever), Grego ${ }^{19}$ (severovýchod), Levante ${ }^{20}$ (východ), Laxaloch ${ }^{21}$ (jihovýchod), Metzo$d^{22}$ (jih), Libetzo ${ }^{23}$ (jihozápad), Ponente ${ }^{24}$ (západ), Magistro ${ }^{25}$ (severozápad).

Nejzápadnějším bodem atlasu (tabule IIIa) je komentář týkající se mytických Iles Beneventurades, Ostrovů blažených či štastných, obvykle ztotožňovaných s Kanárskými ostrovy (jak ostatně naznačuje i popiska Illes Canàries) ${ }^{26}$, jejichž po-

18 Z latinského trans montanis (za horami). Studený vítr foukající od severu až severovýchodu v jižní Francii (tramontane), severní Itálii (tramontana) a severním Katalánsku (tramuntana).

19 Katalánsky grech ( $\mathrm{v}$ dnešní katalánštině gregal), $\mathrm{v}$ dnešní italštině grecale. Silný suchý vítr od severovýchodu; pojmenovaný je podle toho, přichází směrem od Řecka (katalánsky Grècia, italsky Grecia).

20 Katalánsky llevant. Historicky se jako Levanta označuje Blízký východ, na větrné růžici Katalánského atlasu je doplněn křížem, naznačujícím, že východním směrem je Boží hrob v Jerusalemě. Název sám označuje „vycházející; místo, kde vychází Slunce“.

21 Katalánsky exeloch ( $\mathrm{v}$ dnešní katalánštině xaloc), v dnešní italštině scirocco. Silný teplý jižní až jihovýchodní vítr vanoucí ve Středomoří. Vzniká nad Saharou a okolními severoafrickými oblastmi.

22 Katalánsky migjorn. Vítr vanoucí od Středozemního moře. Význam slova je „poledne, polední“ - i v češtině se jižní strana kdysi označovala jako „poledni“ (v protikladu k severní, „půlnočni“).

23 Katalánsky lebeg ( $\mathrm{v}$ dnešní katalánštině llebeig), v dnešní italštině libeccio. Je tak pojmenován podle toho, že vane z Libie (staré označení pro Afriku, neplést s dnešní Libyí).

24 Katalánsky ponent. Čerstvý vítr od západu ve Středomoří. Název sám označuje „zapadající; místo, kde zapadá Slunce“.

25 Z latinského magistralis ventus, „hlavní vítr“. Katalánsky mestre ( $\mathrm{v}$ dnešní katalánštině mestral), $\mathrm{v}$ dnešní italštině maestrale, francouzsky mistral. Suchý a studený vítr od severozápadu.

26 „Illes Canàries. Les iles Beneventurades són en lo mar gran contra la mà squerra prop lo terme del occident, mes però són dintre la mar. Isidori ho diu al se $[u] \cdot X V$. llibre, que aquestes són dites Beneventurades quar de tots bén, blats, fruyts, herbes, arbres són plenes, e los pagans se cuiden que aquí sia paraís per lo temprament del sol e habundància de la terra. Ítem diu Isidòrius que los arbres hi crexen tots almenys.C.XL. peus ab molts poms e molt aucels; aquí ha mel e let, majorment en la ylla de Caprària qui ayxí as apellada per la multitud de les cabres qui i són. Ítem és aprés Canària, illa dita Canària per la multitud dels cans que són en elha molt grans e forts. Diu Pli[ni]us, maestre de mapamundi, que en les yles Fortunades ha una ylla un se leven tots los bén del món, con sense semrar e sens plantar leva tots fruitsen les altees dels monts, los arbres no són nulh temps menys de fulla e de fruits ab molt gran odor; d'assò menyen una part del anys, puis segen les messes en loch derba. Per aquesta raó tenen los pagans de les Índies que les lurs ànimes con són morts sèn van en aquelles 
pis podali Plinius Starší (insuloe fortunatæe) a Isidor Sevillský (též svatý Isidor ze Sevilly, latinsky Isidorus Hispalensis, asi 560-636), a ilustrace rovněž mytického Insula de Brazil. Tento ostrov (jméno nemá s Brazílií nic společného) zaznamenal již Dulcert (Dalorto) na mapě z roku 1325 (či 1330?) pod jménem Insula de montonis siue de brazile. ${ }^{27} \mathrm{~V}$ Katalánském atlase je umístěn na dvou místech: západně od Irska a jižně od Irska. Tuto zvláštnost ostatně najdeme $\mathrm{v}$ tomto díle častokrát, což svědčí, že autor/autoři čerpali $z$ různých pramenů.

Zajímavé je rovněž opakování vyobrazení ostrovů Korsika (Còrsega) a Sardinie (Sardenya) na dvou následných listech (tabule IIIb a IVa), takže uprostřed Středozemního moře (mar de Miga Terra, Mare Miteretaina) vznikla jakási překryvná oblast, která se neopakuje na jiných mapách.

$\mathrm{V}$ Africe najdeme portréty několika panovníků, zejména maliského „Musse Melly“, známého z historických pramenů jako Mansa Musa. ${ }^{28}$ Musa Keita I. (asi 1280-1337, vládl 1312-1337) byl desátým mansou bohaté západoafrické říše Mali (mandingsky Nyani, Manden Kurufaba). V Katalánském atlase je vyobrazen se zlatou mincí. Hlavním městem říše a významným obchodním střediskem bylo Timbuktu, jež se $\mathrm{v}$ atlase objevuje pod jménem Tenbuch.

Mansa Musa byl znám jako podporovatel islámu a nejbohatši člověk historie, jehož království produkovalo nejvíce zla-

yles e viuen per tot temps de la odor d'aquels fruits, e allò creen que és lur paradís, mes segons veritat faula és." [Tyto Ostrovy blažených jsou ve velkém moři na levé straně, pobliž západního okraje, ale stále v moři. Isidor (Sevillský) rríká ve své 15 . knize, že tyto ostrovy jsou tak nazvány proto, že mají nepřeberné množství veškerého zboží, kukuřice, ovoce, bylin a stromů. Pohané věrí, že se tam nachází ráj, protože ostrovy mají takové mírné klima a tak velkou úrodnost půdy. Isidor také říká, že stromy dosahují výšky sto čtyřicet stop, a jsou obtěžkány ovocem a ptáky. Je zde med a mléko, a to zejména na ostrově Caprària, který je pojmenovaný podle množství koz (latinsky caprce). Rovněž je tam ostrov, který nazývají Canària podle množství velkých a silných psů (latinsky canes). Kartograf Pli[ni]us také říká, že mezi Ostrovy štastných je jeden, na kterém všechny dary země se mohou sklízet bez setí a bez pěstování. V horských výškách stromy nikdy nejsou bez listů a plodů, které jsou velmi aromatické. Ty jedí část roku a poté sklízejí obilí místo bylin. $\mathrm{Z}$ tohoto důvodu pohané $\mathrm{v}$ Indii věří, že jejich duše jsou po smrti přeneseny na tyto ostrovy, kde žijí věčně $z$ vưně tohoto ovoce. Proto věří, že jejich ráj je tam. Ale ve skutečnosti je to omyl.] - Grosjean, ed. (1977), 52-53; překlad podle Palomo (2002), 24; Buchon - Tastu (1839), 67-68; Kennedy Jones-Lewis, eds. (2016), 424.

27 Podle irské tradice je odvozeno od Uí Breasail („potomci klanu Breasal"). - Souhrnný přehled kartografických názvů tohoto mytického ostrova viz např. Freitag (2013), 267-298.

28 „Ginyia. Aquest senyor negre és appellat Musse Melly, senyor dels negres de Gineva. Aquest rey és lo pus rich e.l pus noble senyor de tota esta pertida per l'abondànçia de lor lo qual se recull en la suua terra." [Tento černý pán se nazývá Musse Melly a je panovníkem černochů v Guineji. Tento král je nejbohatším a nejvznešenějším pánem celé oblasti vzhledem $\mathrm{k}$ dostatku zlata dobývaného $\mathrm{z}$ jeho země.] Grosjean, ed. (1977), 65; překlad podle Palomo (2002), 29; Nogueira (2013), 290; Buchon - Tastu (1839), 75. ta na světě (kolem jedné tuny ročně). ${ }^{29}$ Jeho pout' do Mekky v roce 1324, během níž navštívil i Káhiru, se stala doslova senzací. Karavanu tvořily desetitisíce poddaných, tisíce otroků a desítky velbloudů naložených zlatem. Musa po cestě rozdával zlato chudým a údajně každý pátek postavil jednu mešitu. ${ }^{30}$ (Pollard - Rosenberg - Tignor 2015, 362) Jeho pout' vyvolala zájem v severoafrických muslimských královstvích a vzbudilo zájem o prozkoumání tohoto kontinentu a odhalení zdroje jeho obrovského bohatství.

V Katalánském atlase je vyobrazena lod' Jauma Ferrera, mallorského mořeplavce 14. století, který se v roce 1346 (na svátek sv. Vavřince, tj. 10. srpna) vydal na plavbu kolem západního pobřeží Afriky, aby našel cestu po Riu del Or (Zlatá řeka) do vnitrozemí Afriky, kde Janované a Katalánci doufali nalézt zlato a slonovinu. ${ }^{31}$ Atlas obsahuje i popis Cap de Finisterra (dnešní mys Bojador na pobřeží Západní Sahary). ${ }^{32}$

Druhá část atlasu, tabule $\mathrm{V}$ a VI, obsahuje rozšíření portolánu na mapu světa (mappa mundi), na což byla mallorská škola zvlášt hrdá. Je zde zachyceno území od Kaspického moře (popsáno je Kaspické pohoří, Monts de Caspis, Muntanyes de Caspis $^{33}$, přes které táhl Alexandr Veliký, Alexandr III. Make-

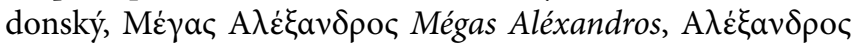

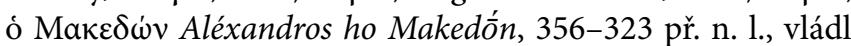
336-323 př. n. 1.) a Perského zálivu (mar de les Índies e de Pèrsia), přes Indii (les Índies) až na východní pobřeží Číny (Catayo). Města známá ze zpráv cestovatelů jsou umístěna často ná-

29 Jeho osobní majetek se odhaduje na 400 biliónů USD v dnešních cenách. - Viz např. Fleming (2012).

30 Náhlý př́liv obrovského množství zlata však dočasně snížil jeho cenu v regionu a zvýšil ceny. Je to jediný případ v dějinách, kdy jediná osoba kontrolovala cenu zlata ve Středomoří.

31 „Partich l'uxer d'en Jacme Ferer per anar al riu de l'or al gorn de sen Lorens qui és a .X. de agost qui fo en l'any.M.CCCXLVI." [Lod', na níž Jaume Ferrer odjel ke Zlaté řece na svatého Vavřince, což je 10. srpna 1346.] - Grosjean, ed. (1977), 55; překlad podle Palomo (2002), 26; Nogueira (2013), 289; Buchon - Tastu (1839), 66.

32 „Cap de Finistera occidental de Àffrica. Assí comença Àffricha e fenex en Alaxandria (var. Alexandria, Alaxendria) e an Babilonia, qui fa comensament açi e comprèn tota la marina de Barbaria ves Allexandria e ves migjorn [e ves] Antiòpia [...]. E an questes plages se trobas molt ivori per la [multitud] d'oriffants [e.l roax que ací arriba e per lo ...]." [Západoafrický mys Finisterre. Zde začíná Afrika a končí v Alexandrii a Babylonii, která má zde počátek a zahrnuje veškeré mořské pobřeží od Barbarie do Alexandrie, na jih [dosahuje až] do Etiopie [...]; a na těchto místech se nachází množství slonoviny od [mnoha] slonů]... (dále text nejasný)] — Grosjean, ed. (1977), 56; překlad podle Palomo (2002), 26; Nogueira (2013), 289; Buchon Tastu (1839), 73.

33 Pohoří je známé od starověku pod řeckým jménem Káođıov ópoc Káspion óros a latinským Caspii montes. Podle různých pramenů označovalo Kavkaz nebo pohoří podél Kavkazu, snad Elburz, a tvořilo severní hranici Perské říše. Katalánský atlas zde zachycuje středověkou legendu, podle níž Alexandr Veliký zde vybudoval proti národům Gog a Magog bariéru, aby jim zabránil postupu na jih. Pojem „Alexandrova brána" se objevuje ve středověké literatuře již od 6. století. Často je identifikována s Kaspickou bránou (latinsky Portee Athance či Portee Caspice) v Derbentu v Dagestánu. 
hodně na plochu nebo na pobřeží, prázdné místo je vyplněno vyobrazeními z Bible (např. Gog a $\operatorname{Magog}^{34}$ ), ze světa pověstí a ze zpráv cestovatelů.

Společné pro tyto dvě části je, že mapa znázorňuje mnoho vyobrazení měst, jejichž politické vazby jsou symbolizovány vlajkami. Křestanská města označuje kř́iž, ostatní města chrám. Moře a oceány jsou vyznačeny modrými vlnitými vodorovnými čarami. A jak je běžné u námořních map, jsou místní jména důležitých př́istavů napsána červeně, ostatní černě.

Tabule V a VI, které nepatří do kategorie portolánových map, jsou kompilovány, stejně jako texty na tabulích I a II, z rozličných pramenů. Autor předlohy mapy Asie pravděpodobně znal ptolemaiovské mapy ${ }^{35}$, protože zde najdeme řadu útvarů převzatých $\mathrm{z}$ těchto map, ale $\mathrm{v}$ některých př́padech špatně umístěných. Autor naprríklad zaměnil (alespoň v propiskách) ostrovy Cejlon a Jávu. Na vyobrazení Cejlonu je popiska Illa Iana (= Iaua) a na ostrově Jáva Illa Trapobana. ${ }^{36}$

Třetí část atlasu obsahuje na tabulích I a II kompilaci kosmografických, astronomických a astrologických textů přeložených do katalánštiny. Tyto texty zdůrazňují sférický tvar Země a stav současného světa, poskytují rovněž užitečné informace pro námořníky o př́livech a odlivech a jak počítat čas v noci. Texty doprovází několik ilustrací: tabulka přílivů a odlivů, věčný kalendář a velký graf orámovaný čtyřmi ročními obdobími, jenž podává informaci o zvěrokruhu, sedmi známých planetách a diagram souhvězdí.

34 Gog a Magog jsou jména, která se objevují jak v Starém zákoně (Gog u-Magog), tak v Koránu (Ya'ğ ūğ wa-Ma'ğ $\bar{u} g$ ). Od starověku do pozdního středověku označují eurasijské nomády, „severní barbary“. V Katalánském atlase jsou označeni jako Tataři (los Tartres Gog e Magog). Vyobrazen je i jejich vládce s popiskou: „Lo gran seynor, princep de Gog e de Magog. Aquest exira en temps d'Antechrist ab molt gent. " [Velký pán, kníže Gogu a Magogu. Přitáhl v době Antichrista s mnoha lidmi.] — Grosjean, ed. (1977), 92; překlad podle Palomo (2002), 51; Buchon - Tastu (1839), 146.

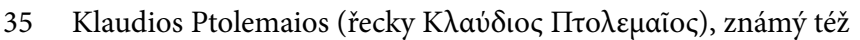
pod latinskou podobou jména Claudius Ptolemæus (asi 85-asi 165), byl řecký geograf, astronom a astrolog, který pravděpodobně žil a pracoval v egyptské Alexandrii. Geografie je podle Ptolemaia „lineárním zobrazením veškeré nyní známé Země, se vším, co se na ní nachází. S pomocí matematiky umožňuje „přehlédnout celou Zemi na jediném obraze podobným způsobem, jakým můžeme pozorovat otáčející se nebeskou báň nad svou hlavou", ale pouze v hrubých rysech. Ptolemaiova geografie bývá často chápána jako počátek obecné geografie či obecné zeměvědy. Jeho práce byla biblí pro geografy období renesance a velkých geografických objevů.

36 Viz Grosjean, ed. (1977), 90-91 a 94-95; Palomo (2002), 50, 57; Buchon - Tastu (1839), 137-138. Na ptolemaiovských mapách má Cejlon jméno Taprobana (nebo Taprobanes Insula) v souladu s antickou tradicí. Támraparní („list v barvě mědi“) bylo jedno ze starých domácích jmen Cejlonu. $Z$ toho vzniklo někdy ve 4 . století př. $n$. 1 .

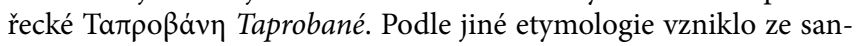
skrtského Tambrapani („velký rybník“, „rybník pokrytý červeným lotosem“). Existují i další teorie.

\section{ASIE V KATALÁNSKÉM ATLASE}

Atlas vycházel z různých pramenů, o čemž svědčí mimo jiné i zobrazení území Indie, které zachycuje politické rozdělení na sever a jih. Tehdy v severní Indii vládl Dillíský sultanát (urdsky Soltanat-e Dillī, též Soltanat-e Hind, 1206-1526), jižní Indie byla ovládána množstvím států, po roce 1336 pak mocnou Vidžajanagarskou říší (kannadsky Vijayanagara sāmrājya, telugsky Vijayanagara sāmrājyamu, 1336-1646). V severní Indii je proto vyobrazen „král Dillí, velký sultán“ (lo rey Delli, soldà gran), zatímco v jižní Indii „král Kolomba“ (lo rey Colo[m]bo). (Grosjean, ed. 1977, 86-87; Palomo 2002, 43-44; Buchon and Tastu 1839, 123-124) ${ }^{37}$

Hlavním pramenem pro mapu Asie v Katalánském atlase byl cestopis Marka Pola (asi 1254-1324), benátského kupce a jednoho z nejvýznamnějších středověkých cestovatelů do východní Asie, který v letech 1271-1295 podnikl se svým otcem Niccolou (Nicolò [di San Giovanni Crisostomo], zemřel před 1300) a strýcem Matteem (Matteo, Maffio, zemřel před 1318) cestu přes střední Asii do Číny a řadu let pobýval na dvoře chána Chubilaje (mongolsky Qubilai qayan, v Evropě znám jako Kublajchán, 1215-1294, Veliký chán 1260-1294, císař mongolské Číny 1271-1294) - na mapě vyobrazen a označen jako Holubeim..$^{38}$ Katalánský atlas zachycuje přibližnou expanzi Mongolské říše rozmístěním různých vlajek, které však se skutečnými vlajkami nemají moc společného. Podobné vy-

37 Grosjean ve svých vysvětlivkách uvádí, že se jednalo o Vidžajanagarskou říši, to však není pravděpodobné. Vidžajanagarská říše sice ovládala jižní Indii v době vzniku atlasu (v letech 1336-1649), ale jejím hlavním městem nebylo „Kolombo“, ale Vidžajanagar (dnešní Hampi ve střední Karnátace). Jako „Kolombo“ (Colo[m]bo) je zde míněn významný př́stav Kollam (Quilon) v jižní části Malabárského pobřeží Indie, v dnešním indickém státě Kérala. Ve 13.-14. století to bylo velké obchodní centrum a do 14. století konečný přístav lodí plujících z Číny do Indie. Z Kollamu se kromě tranzitního zboží, zejména koření ze Sumatry, Jávy a Cejlonu, vyvážely místní „jemné druhy“, zejména byl proslavený kollamský zázvor a barvířské dřevo. Předpokládáme-li, že pramenem informací byl Marco Polo, popřípadě Odorik z Pordenone (oba Kollam popisují), jedná se s největší pravděpodobností o Ravivarmu Kulašékharu (vládl 1299-1314), nejvýznamnějšího panovníka místního Vénádského království (malajálamsky Vēnạt svarūpam, 12. století-1729) s centrem v Kollamu. Katalánský atlas zde uvádí, že král je „křestan“" (Açi seny[o]reja lo rey Colo[m]bo, christià. „Zde vládne král Kolo[m]ba, křestan.“). Král nebyl křestan, ale v Kollamu byla křestanská kolonie. Na mapě je přítomnost křestanů naznačena vlajkami s křížem.

38 „La major príncep de tots los tartres ha nomn Holubeim, que vol dir gran Ca. Aquest emperador és molt pus rich de tots los altres enperadors de tot lo món. Aquest emperador guarden ·XII. [míllia] cavallés e han IIII. capitans. Aquests ·XII. cavallés e cascú capità [és] en la cort ab sa copanya per -III. [meses] de l'any, e axi dels altres per [orde]." [Kníže nejmocnější ze všech Tatarů zvaný Holubeim, což znamená Veliký chán. Tento císař je daleko bohatší než jakýkoli jiný vládce světa. Tohoto císaře chrání dvanáct tisíc jezdců, kteří mají čtyři kapitány. Každý ze čtyř kapitánů se svými vojáky slouží na dvoře tři měsíce v roce, a tak se vystř́ídají všichni.] — Grosjean, ed. (1977), 93; překlad podle Palomo (2002), 54; Buchon - Tastu (1839), 141. 


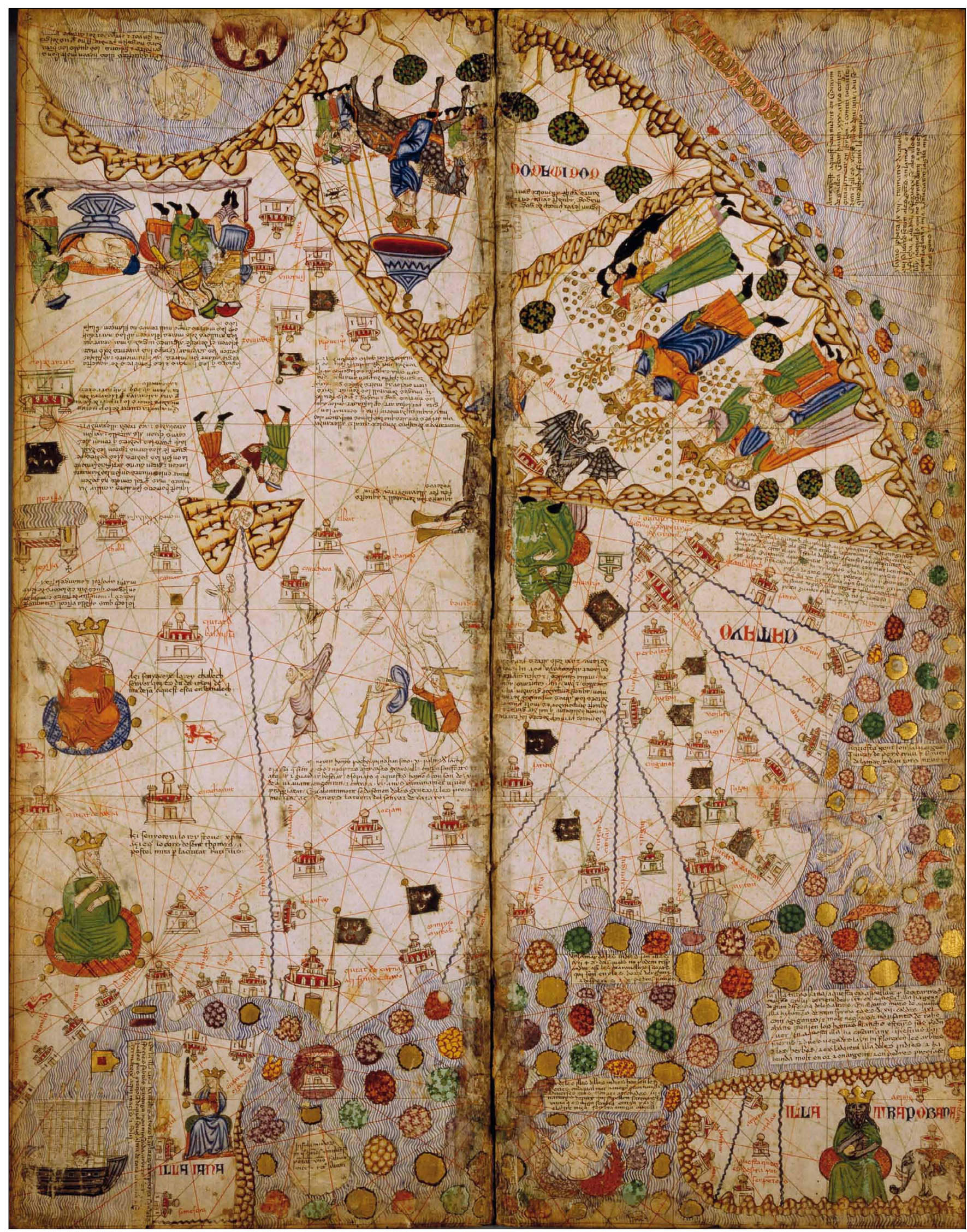

Obr. 4. Katalánský atlas, tab. VI, zachycující východní polovinu Asie. Uprostřed je podobizna chána Chubilaje (Holubeim). (Paris, Bibliothèque nationale française, Richelieu Manuscrits Espagnol 30) 
obrazení je známo i z jiných map, napríklad portolánových map bratrů Piziganů..$^{39}$

Ve střední Asii, na slavné Hedvábné cestě z Číny přes Tarimskou pánev do západní Sibiře a na Levantské pobřeží Středozemního moře, využil maliř atlasu prázdné místo pro nejbohatší a nejkrásnější motiv celého díla, velbloudí karavanu následovanou skupinou kupců jedoucích na koních. ${ }^{40}$

Atlas obsahuje řadu zajímavých etnologických, hospodářsko-geografických a obchodních informací převzatých ze zpráv cestovatelů. Dozvídáme se napríklad, že Baghdád (Baldacha) je důležitým obchodním místem pro koření a vzácné zboží z Indie. Podobně zjištujeme např́íklad, že Jemen (Ara-

39 Bratři Francesco a Domenico Piz(z)igano (fratelli Pizigani) byli benátští autoři map, zejména mapy z roku 1367, tedy současníci tvưrců Katalánského atlasu.

40 Vyobrazení na listě Vb doprovází text: „Aquesta caravana és partida del imperi de Sarra per anar a Alcatayo." [Tato karavana se vydala z říše Sarra na cestu do Číny]. - Grosjean, ed. (1977), 85; překlad podle Palomo (2002), 38; Buchon - Tastu (1839), 130131. Na protějším listě Va je však daleko podrobnější popis cesty od města Lop přes poušt', evidentně převzatý od Marka Pola: „Sapiats que aquells qui volen passar aquest desert estan e [re]posen per tota una setmana contínuament en una ciutat appellada Lop en la qual ells e lurs bèsties recréan, puys [pren] en lurs necessaris per $\cdot V I I$. meses, car per tot lo desert va [hom] II. dia e una nit abans que hom puxa trobar aygua bona a beure, mas de dia en dia e nit ne troba hom tanta que abasta de $\cdot L \cdot$ en .C. persones o a més; e si.s esdevendrà [que de] nit cavalcant algú agreujat se adorma o en altra cosa [era] per què leix los altres companyons, sovén sesdevé que ou [en l'aer] veus de diables semblants a les veus dels companyons [encara] que.l nomenen per son nom propri, per què los [diables] lo ménan tant deçà e dellà per lo desert axí con [companyons] seus que null temps no pot trobar sos companyons. E d'aytal desert $\cdot M \cdot$ novelles ne són sabudes. " [Vězte, že ti, kteř́i chtějí překročit tuto poušt', zastaví a odpočinou si po dobu jednoho týdne ve městě jménem Lop, kde si cestující a jejich koně obnoví síly. Poté si vezmou vše, co budou potřebovat na cestu trvající sedm měsíců, protože na poušti stráví celou noc a den, než najdou vodu. Nicméně každý den a půl ji najdou dost, že vystačí pro padesát nebo sto, či dokonce více lidí. $A$ když je někdo na koni v noci, unaven $\mathrm{z}$ cesty, usne nebo $\mathrm{z}$ jakéhokoli jiného důvodu se vzdálí od svých společníků, často slyší hlasy dáblů podobné hlasům svých společníků, které ho volají jeho vlastním jménem, a dáblové ho tak vedou pouští sem a tam, že nikdy nenajde své společníky. O této poušti existují tisíce př́iběhů.] - Grosjean, ed. (1977), 82; překlad podle Palomo (2002), 38-39; Nogueira (2013), 294-295; Buchon - Tastu (1839), 130. „Sarra“, jak vyplývá $\mathrm{z}$ textu na jiném místě atlasu, je Saraj na dolním toku Volhy, hlavní město chanátu Zlatá Horda (turkicky Altın Urda, též Kypčak, 1241-1480), se 600000 obyvateli jedno z největších měst stř̌edověku. „Açí està l'emperador de aquesta regió septentrional, del qual lo imperi comença en la província de Burgària e feneix en la ciutat de Organcio. Lo senyor és appellat Jambech, senyor del Sarra." [Zde je císař této severní oblasti, jejíž říše začíná v provincii [Volžské] Bulharsko a končí ve městě Organcio (= Urgenč). Panovník se nazývá Jambech, pán Sarry.] — Grosjean, ed. (1977), 82; překlad podle Palomo (2002), 38; Nogueira (2013), 292; Buchon - Tastu (1839), 129. Zmíněným panovníkem byl Džanibek (vládl 13421357), poslední velký vládce Zlaté Hordy před jejím rozpadem. bia Sebba $)^{41}$ produkuje myrhu, kadidlo a jiné aromatické látky, ostrov Iana aloe, kafr, santalové dřevo, muškát apod. ${ }^{42}$ Atlas zachycuje řadu míst židovské i křestanské tradice, ve dvou prŕpadech i hroby apoštolů: sv. Matouše v klášteře arménských bratří u jezera Issyk-Kul (kyrgyzsky Ысыккөл Ysykköl, rusky Иссык-куль Issyk-kul', „teplé jezero“) ${ }^{43}$ a sv. Tomáše v Mailapúru v jižní Indii ${ }^{44}$. Z atlasu je zřejmá tendence nahlížet na svět očima křestana - což by napovídalo, že autorem původní předlohy byl křestan a Cresques (žid) pouze kopíroval texty a postaral se o iluminaci. I ve vzdálených oblastech Asie je často uvedeno, že obyvatelé či panovníci jsou křestané. Najdeme i nějaké informace o islámu, nicméně i zde se objevuje v té době běžný omyl, že Mohamedův hrob se nachází v Mekce. ${ }^{45}$

41 Odkazuje na Sabejské království (8. století př. n. 1.-275 n. 1.) a legendární královnu ze Sáby: „Arabia Sebba. Província la qual és aquella que tania la ragina Sebba. Ara és de sarrayns alhàrabs e ay moltes bones odós axi com de mirra e d'ensens e és abundade en or, en argent e en péres preciosses e encara, segons diu, hi és atrobat un auçell que ha nom ffenix. “ [Provincie, která vládla královna ze Sáby. Nyní patří saracénským muslimům a nachází se tam mnoho aromatických látek, jako kadidlo a myrha. Je bohatá na zlato, stř́bro a drahé kameny, a ještě, jak říkají, se tam nachází pták jménem fénix.] — Grosjean, ed. (1977), 84; překlad podle Palomo (2002), 42; Nogueira (2013), 294; Buchon - Tastu (1839), 119.

42 Text se skutečně týká Jávy (viz např. popis u Odorika), pouze popiska s názvem ostrova je na mapě chybně umístěna na místě Cejlonu. „Illa Iana. En la illa Iana ha molts arbres lianyloes, càmphora, sàndels, spècies subtils, garenga, nou moscada, arbres [de canyella, la] qual és pus preciosa de qualsevol altra de tota la India, e són axí mateix aquí maçís e folii." [ $\mathrm{Na}$ ostrově Iana se nachází spousta stromů aloe, kafr, santalové dřevo, jemné koření, galgán (= druh zázvoru), muškátový oříšek a skořicovník, který je cennější než jakýkoli jiný v Indii. A jsou tam jak muškátové květy, tak listy.] — Grosjean, ed. (1977), 91-92; překlad podle Palomo (2002), 50; Buchon - Tastu (1839), 137.

43 „Lo loch qui.s appella Ysicol. En aquest loch és .I. monestir de frares ermenians on, segons que.s diu, és lo cors de sent Mathei apòstol e evangelista." [Místo, které se nazývá Issyk-Kul. Zde je arménský klášter mnichů, v němž je, jak říkají, tělo svatého Matouše, apoštola a evangelisty.] - Grosjean, ed. (1977), 89; překlad podle Palomo (2002), 48; Buchon - Tastu (1839), 132-133. Tato legenda o hrobě sv. Matouše právě na tomto místě se ještě objevuje na kruhové Mappa mundi z Velletri (kolem 1430), dnes uložené ve Vatikánské knihovně (Ms. Borg. lat. XVI): „Ysicol lacus super quem corpus beati mathei quievit" [Jezero Issyk-Kul, u nějž spočívá tělo blahoslaveného Matouše.] - Schmieder (2012), 255-256.

44 „Açí senyoreja lo rey Steve, christià. Açí és lo cors de sent Thomàs apòstel. Mira per la ciutat Butifilis. “ [Zde vládne král Štěpán, křestan. Zde se nachází tělo svatého Tomáše apoštola. Podívej se na město Butifilis]. - Grosjean, ed. (1977), 90; překlad podle Palomo (2002), 50; Buchon - Tastu (1839), 135-136. Katalánský atlas, kromě toho že odkazuje na město Butifilis (dnešní Motupalle, jihozápadně od města Masulipatam, $v$ indickém státě Ándhrapradéš), rovněž zaznamenává Mailapúr (Mirapolis) v Tamilnádu, tedy místo, kde je podle legendy hrob sv. Tomáše. Vzdálenost mezi oběma místy je asi 500 kilometrů.

45 „Ciutat de Mecha. Mecha. En esta ciutat és larcha de Mafumet, proffeta dels sarrayns, los quals vénan açi de totes lus regions en 
Důležitým pramenem pro Katalánský atlas byl cestopis Odorika z Pordenone (mezi lety 1275 a 1285-1331), zejména pro území Číny - jsou uvedena některá města, která u Marka Pola chybějí. Čínu (Catayo) zachycuje tabule VI. Tuto část bylo pro autory zřejmě nejobtí̌žnejší zkompilovat. Nedostatek zeměpisných informací je řešen bohatou dekorací. Orografie a hydrografie nejsou typické pro ostatní mapy - zde jsou spíše dekorativním prvkem $\mathrm{k}$ orámování ploch. Podobnému účelu slouží i vegetace.

Nejlepší zeměpisnou informací jsou města, zejména nejdůležitější z nich Chanbalech, Chánbalyk (persko-turkicky Hān Bālīq / Qan-baliq, čínsko-mongolsky 汗八里 Qanbaliq, „Chánovo město“, dnešní Peking), hlavní město říše Velikého chána (mongolsky Yeke Mongyol-un Yuvan Ulus), bohatě popsané Markem Polem i Odorikem. Hlavní město Chubilajovy říše bylo vlastně dvojměstí, skládající se ze starého Chánbalyku a nového Ta-tu (大都 Dàdū, „Veliké město“). ${ }^{46}$ Tuto skutečnost zachycují všechny cestopisy, včetně Marka Pola a Odorika. Město je zakresleno na mapě jako dvě spojená města a jeho význam podtrhuje vedle dlouhého textu i trojí uvedení jména: ciutat de Chambalech, Magni Canis Catayo (město Chánbalyk, [rezidence] Velkého chána Číny), a 2x Chanbaleth (z obou stran kresby). ${ }^{47}$

pelegrinatge e dien <e dien > pus an vista ten preçiossa cossa, que no són dign[es] de pus veser, e aquí éls s'anbaçinan la vista en reverència de Mufumet." [Mekka. V tomto městě je hrob Mohameda, proroka Saracénů, k němuž přicházejí poutníci ze všech oblastí a říkají, že poté, co viděli takovou cennou věc, již není nic, co stojí za vidění. A zastírají (vypalují?) si oči na počest Mohameda.] — Grosjean, ed. (1977), 84; překlad podle Palomo (2002), 42; Nogueira (2013), 294; Buchon - Tastu (1839), 118.

46 V roce 1215 Mongolové dobyli hlavní město džürčenské řiše Ťin (džürčensky Amban Anchun gurun, čínsky 金朝 Jinn Cháo, 1115-1234) Čung-tu (中都 Zhōngd̄u, „Prostřední hlavní město“), ležící na území Pekingu (jihozápadně od centra dnešního města, kolem chrámu Tchien-ning-s', 天寧寺 Tiānning Si), a obnovili jeho starobylé jméno Jen-ting (燕京 Yànjīng). Roku 1260 sem chán Chubilaj přestěhoval hlavní město říše, které dosud bylo v Karakorumu (pobliž dnešního Charchorinu) na horním toku řeky Orchon, a město se začalo nazývat Chánbalyk. V roce 1267 byla zahájena výstavba nového města asi půl míle severovýchodně, kam byl po jeho dokončení roku 1272 přestěhován dvưr a státní správa mongolské rríše Jüan. Nové hlavní město dostalo jméno Ta-tu, a je vlastním počátkem dnešního Pekingu.

47 Text vychází z popisu Marka Pola: „Sapiats que costa la ciutat de Chambalech avia una gran ciutat antigament qui avia nom Guaribalu e lo gran Cha trobà per l'estornamia que aquesta ciutat se devia revelar contra él, axi que féu-la desabitar e féu fer aquesta ciutat de Chambalech. E a environ aquesta ciutat ·XXIIII- legües, e és molt ben murada $e$ és a cayre, si que a cascun cayre ha VI. legües, e ha d'alt $\cdot X X \cdot$ pases e -X. pases de gros, e ay XII. portes e ay II gran torra en què sta un seyn qui sona a prin son o abans, axi pus ha sonat no gossa anar negun per villa, e a cascuna porta guarden mill hòmens no per temenssa mas per honor del senyor." [Vězte, že vedle města Chánbalyk bylo v dávných dobách veliké město, které mělo jméno Guaribalu. Veliký chán zjistil prostřednictvím astronomie, že se toto město musí přemístit naproti němu. Nechal přestěhovat jeho obyvatelstvo a postavit město Chánbalyk. Toto město má obvod 24 mil, je velmi dobře opevněno a má čtvercový půdorys. Každá strana je dlouhá 6 mil a je vysoká 20 kroků a silná 10 kroků a má 12 bran a jednu velkou věž, na níž visí velký zvon, který bije v hodině prvního spánku [tj. večer] nebo dřive.
Katalánský atlas zachycuje na listě VIb celou řadu vnitrozemských a pobřežních měst jihovýchodní a východní Číny. Některá jsou zakreslena na správném místě, jiná jsou umístěna chybně, některá se nedají identifikovat vůbec. Autoři čerpali opět zejména z Marka Pola, některá města, např. Zayton ${ }^{48}$, Fogo $^{49}$ a Mingio $^{50}$ však najdeme i u Odorika. Některá města jsou zakreslena několikrát, jak autoři čerpali z různých zdrojů: ciutat de Zayton, Zayton; Fugio, Fogo; Caysam, ciutat de Cansay $^{51}$. (Grosjean, ed. 1977, 93) Na mapě jsou schematicky zakresleny i hlavní řeky propojené kanály.

Hranicí Číny je řeka Indus (flum Indi) s2 $^{52}$ která podle dobové tradice pramení v pohoří velkých rozměrů, pravděpodobně Himálaj. Na jih od Číny je zakresleno množství ostrovů v Indickém moři a udán jejich počet (7 548) v souladu s popisem u Marka Pola (podle různých rukopisů 7 448, 7459 apod.), který je však klade do Čínského moře. ${ }^{53}$

Když zazní, nikdo už nesmí vycházet do města a na každé bráně střeží tisíc mužů - nikoli kvůli strachu, nýbrž pro čest pána.] - Grosjean, ed. (1977), 92-93; prreklad podle Palomo (2002), 55; Buchon - Tastu (1839), 143, 144. - Text evidentně čerpal z Marka Pola - i s chybami. Italská verze totiž jmenuje původní město Garibalu (zkomolené Canbalu) a nové Canblau (kap. 84). Starofrancouzská verze však správně uvádí Taidu. — Srovnej např. toskánskou verzi v Polo (2003), 129-130 a starofrancouzskou v Divisament (2006), 420.

48 Odorikův Zayton, což je arabsko-perský Zaytūn, byl identifikován s Čchüan-čou (泉州 Quánzhōu). Arabský název města údajně vychází z tehdejšího lidového pojmenování tohoto města jako Cch'-tchung-čcheng (刺桐城 Citóng Chéng) odvozeného od jména stromu cch'-tchung (Erythrina variegata, syn. E. indica Lam., E. variegata var. orientalis (L.) Merr.), který se v okolí pěstoval od 10. století.

49 Fu-čou (福州 Fúzhōu). U Odorika se objevuje v podobě Fucho, Fozo apod., u Marka Pola Fuguy, Fugiu apod.

50 Ning-po (寧波 Níngbō). U Odorika se objevuje v podobě napr. Menzu. Zaznívá v něm jméno Ming-čou (明州 Míngzhōu), staré prefektury se střediskem v dnešním Ning-po (v letech 738-1133).

51 Město Chang-čou (杭州 Hángzhōu), před rokem 1276, kdy bylo dobyto Bajanem (mongolsky Bayan čingsang, čínsky Pa-jen čcheng-siang伯顔丞相 Bàyán chéngxiàng, 1236-1295), generálem chána Chubilaje, hlavní město jihosungské říše (v evropských pramenech „Manzi“), se stalo známým již z popisu Marka Pola. Možná Odorik tento popis znal a konfrontoval ho se skutečností. $\mathrm{V}$ té době se nazývalo Lin-an (臨安 Lín’ān), dnešní jméno dostalo až za dynastie Ming. Evropský název Quinsay, Chinsai, Campsay, Cansaia, Casaie apod. byl odvozen od arabského al-Chansá (al-Hansā), tento název pak zřejmě od čínského označení sing-caj (行在 xíngzài), respektive sing-caj-suo (行在所 xíngzàisuǒ), tj. dočasné sídlo panovníka.

52 Zmíněn stručně v kosmografické části, tabule I. - Viz Grosjean, ed. (1977), 42; Nogueira (2013), 274; Buchon - Tastu (1839), 9.

53 „En la mar de les Indies són illes 7548, dels qual no podem respondre assi les marravellozes cozas qui són en eles d'orr, d'ergent e d'espècies e de pedres precioses." [V Indickém moři je 7548 ostrovů, o nichž nemohu vypovědět všechny pozoruhodné věci, pokud jde o zlato, stř́bro, koření a drahé kameny.] — Grosjean, ed. (1977), 94; překlad podle Palomo (2002), 56; Buchon - Tastu (1839), 138. Odorik naproti tomu uvádí v Indickém moři 24000 ostrovů: ,...quod bene xxiiii milia contineat insularum" - PRAHA, Knihovna Národního muzea, XVII.E.2. (Březnice) (Kolowrat.178), f. $6 v b$. 


\section{KATALÁNSKÁ MAPA Z ESTENSE}

Mapa katalánské školy z let 1450 až 1460, nacházející se nyní v Biblioteca Estense v Modeně (C.G.A.1), patří do kategorie mappe mundi, tedy map známého světa. (Milano, ed. 1995; Kretschmer 1897) Z této kategorie však poněkud vybočuje tím, že zachycuje nejen země známého světa, ale i země předpokládané, ještě neobjevené. To značně ztěžovalo kartografovu úlohu, nebot' to znamenalo, že byl neustále staven před problém výběru mezi nedostatečnou a často chabě podloženou skutečností na jedné straně a hodnověrnou a často dobře doloženou teorií na straně druhé.

Koneckonců právě pečlivé hodnocení fakt představovalo jeden z hlavních úspěchů katalánské kartografické školy. Hodnota katalánských map jako záznamů stavu tehdejších znalostí byla zřejmá a nepřekvapuje, že Katalánský atlas 1375 má nejpečlivější vykreslení Asie, jaké do té doby bylo zhotoveno, a že, pokud jde napríklad o znalost Číny a Súdánu, byl překonán až roku 1459 mapou Frà Maura (15. století).

Je třeba zdůraznit, že všechny katalánské mapy, s výjimkou právě mapy světa $z$ Estense, která byla poslední v řadě, se na jižní straně zastavily někde kolem rovnoběžky Sierra Leone, tedy tam, kam tehdejší znalosti zřejmě sahaly. Jako př́klad, jak katalánská kartografická škola vstřebávala geografické znalosti, můžeme uvést Rio del Oro (Zlatá řeka). $\mathrm{Na}$ začátku katalánského období se tato řeka, jako dědictví klasické geografie, vlévala do Atlantského oceánu přímo jižně od mysu Bajador v Západní Sahaře. S rozvojem transsaharského obchodu ve 14 . století a se současným rozšířením geografických znalostí, se Rio del Oro posouvalo postupně stále jižněji, až na katalánské mapě z Estense je umístěno přibližně na úrovni říčního systému Senegal-Niger, který má bezpochyby reprezentovat.

Do poloviny 15 . století pro tento problém vylad’ování informací různého typu existovalo několik vážných překážek. Námořní výzkumné plavby začaly pomalu přinášet ovoce, zatímco pozemní objevné cesty Polů a jejich současníků neprošly ještě revizí. Situace se ještě zostřila s rozvojem portugalských námořních plaveb a rozšiřování horizontů známého světa směrem na jih. Každý kartograf se s tím musel znovu potýkat a neexistují dvě mapy světa, které by ve stejné době poskytovaly ten samý pohled na svět. Můžeme např́ílad srovnat katalánskou mapu z Estense, Walspergerovu mapu světa ${ }^{54}$ a tzv. janovskou mapu světa (Biblioteca Nazionale Centrale, Florence, Italy, Port. 1) $)^{55}$, které všechny vznikly kolem roku 1450.

Na katalánské mapě z Estense lze vypozorovat nejméně tři různé vlivy, vedle tradice portolánových map: klasický, křestanský a arabský. Nejsilnější je arabský vliv. Mapa nenavazuje př́mo na ptolemaiovskou tradici: její autor svou představu o jižním kontinentu převzal od arabských nebo křestanských kosmografů, jako byli Abú'l Fidá ( $A b \bar{u}$ 'l-Fidā', 1273-1331) či Isidor Sevillský, kteři ptolemaiovskou tradici

54 Andreas Walsperger (nar. asi 1415, doba úmrtí neznámá) byl německý kartograf 15 . století.

55 K ní viz např. Brunnlechner (2013).

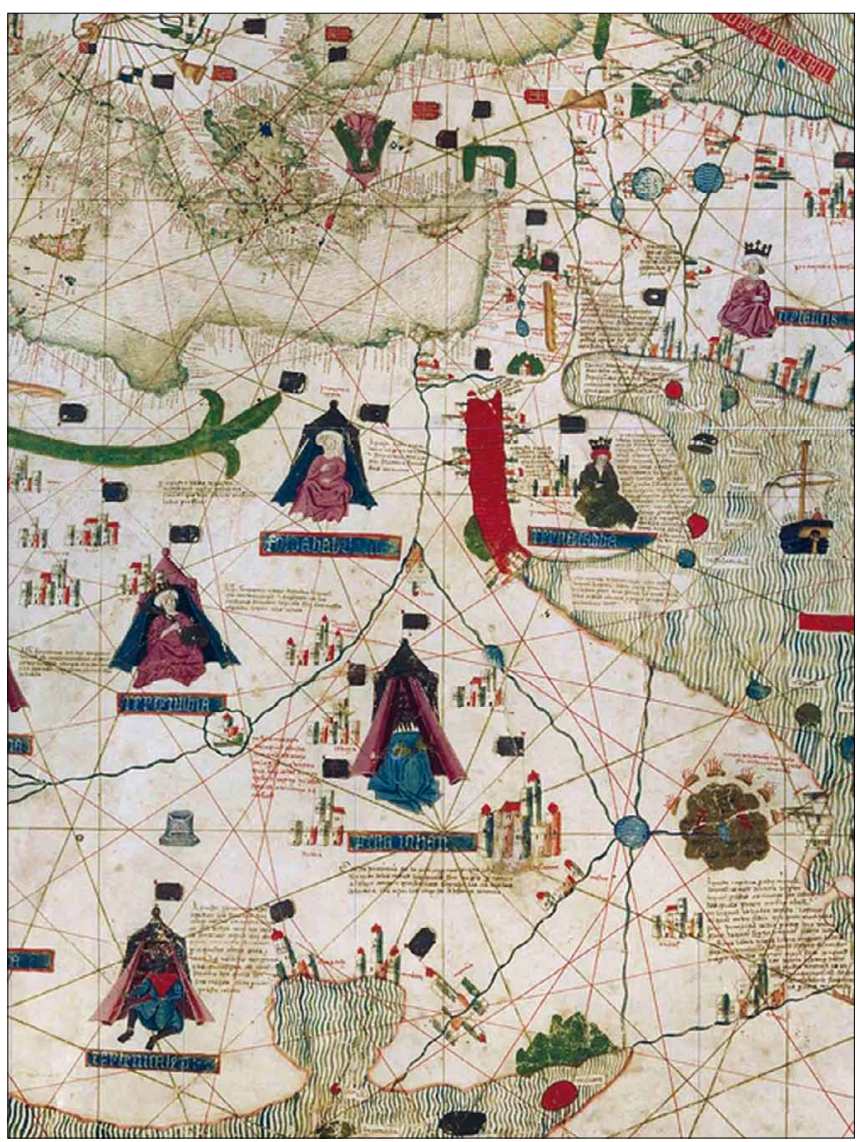

Obr. 5. Pozemský ráj a vyobrazení kněze Jana na mapě z Estense. (zdroj: $<$ http://angloethiopian.org/publications/articles.php?type $=$ L\&reference $=-$ publications/articles/2011spring/paradise.php $>$ )

oživili. Vliv středověké křestanské tradice na katalánské mapě z Estense je zřejmý např. z legendy o knězi Janovi či vyobrazení pozemského ráje ${ }^{56}$. Zatímco legendární křestanský kněz Jan je v Katalánském atlase uveden pouze stručnou

56 „A questa ragio es paradís teranall lo quall es molt delitable loch en lo qual paradis as murat tot le foch los quals puien trofins alcell en lo quall es larbre de uida lo fruyt del qual arbre se diu que q. . manjaua seria jnmortal del dit paradis hix una ffont la qual separatix en quat' parts la hu . e eufrates laltra triges (!) laltra trageon (!) laltra frixon de ualamt del qual aygua fa tan fort brogit que los qui nexe nexen sorts de aquest lac parla ysodorus dient que paradis teranall es en miga de laquinocsiall lo qual es molt delitable loch sens comparacio an lo quall es paradis teranall.“ [Tato země je pozemský ráj, který je radostiplným místem. V něm je ráj obehnán ohništi, [jejichž plameny] šlehají až k nebi, a v něm stojí strom života. Ríká se, že ten, kdo pojí ovoce tohoto stromu, bude nesmrtelný. $Z$ uvedeného ráje vychází pramen, který je rozdělen na 4 části: jednou je Eufrat, další z Tigris, třetí Geon, čtvrtou Phison. Silou té vody vzniká tak silný hukot, že ti, kdo tam přicházejí na svět, se rodí hluší. $\mathrm{O}$ tomto jezeře mluví Isidorus. Říká se, že pozemský ráj se nachází uprostřed rovníku. Je to radostiplné místo, jež nemá srovnání, v němž se nachází pozemský ráj.] (Kretschmer 1897, 86) 
popiskou u Núbie ${ }^{57}$, katalánská mapa $z$ Estense přináší i jeho podobiznu a rozsáhlejší text. ${ }^{58}$

Arabský vliv je jasně patrný, když porovnáme zobrazení jižní poloviny Afriky na katalánské mapě s popisem pobřeží Jižního oceánu u arabského autora 11. století, al-Birúního $(A b \bar{u}$ 'r-Raihāon Muḥammad ibn Aḥmad al-Bīrūnī, persky Abū Raihān Bērōnī/Bīrūnī, 973-1048). A i když je mapa ozdobená opevněnými městy, loděmi a portréty afrických knížat, snaží se poskytnout co nejaktuálnější obraz světa a vyřešit starý problém dosud neobjevené Afriky.

Afrika zabírá většinu jižní poloviny mapy a končí velkým obloukem, který se rozšiřuje směrem na východ, kde tvoří jižní hranici Indického oceánu. Jižní vnitrozemí Afriky je prázdné až na legendu „Africha comensa al flum de nilles en les parts degipta e fenex en Gutzola uert ponent circuit tota la barbaria e la part de mig jorn." [Afrika začíná u řeky Nil v Egyptě a končí u Gutzoly na západě: zahrnuje celou Barbarii a část jihu.] (Kretschmer 1897, 83) ${ }^{59}$ Tato legenda i vyobrazení ukazují na jistou znalost jižního konce Afriky a snad i cesty od západního pobřeží do Indického oceánu.

Kruhová katalánská mapa z Estense o průměru $113 \mathrm{~cm}$ je velmi barevná s vyobrazením velkého počtu afrických knížat (včetně zmíněného kněze Jana $v$ Etiopii), 52 popiskami, vyobrazením opevněných měst pro velká sídliště, loxodrom (tedy křivek svírajících se všemi poledníky stejný úhel), lodí, mořských panen, domestikovaných sobů a koní.

I když téměř o sto let mladší než Katalánský atlas z roku 1375 je katalánská mapa $z$ Estense s ním jasně př́buzná. Tato podobnost obsahu obou map posiluje tvrzení, že Katalánský atlas byl odvozen z kruhového prototypu. Četné popisky $\mathrm{v}$ mapě $\mathrm{z}$ Estense, většinou $\mathrm{v}$ katalánštině či deformované latině, jsou často velmi podobné legendám v Katalánském atlase. Někdy jsou úplnější, jindy zase méně podrobné. Zdá se, že nebyly přímo kopírovány, ale měly společný zdroj. Je to vidět i ze zakreslení hlavních objektů, kdy většinu $\mathrm{z}$ těch, co jsou zakresleny na atlase $\mathrm{z}$ roku 1375 , najdeme i na mapě $\mathrm{z}$ Estense.

57 „[...] ciutat de [Núbia]. Aquest rey de Núbia està [tots temps] en guerra e armes [ab los] chrestians de Núbia qui són so[ts] la senyoria de l'emperador de [Etiò]pia e de la terra de Preste Johan." [... město v Núbii. Tento král Núbie je neustále ve válce s núbijskými křestany, kteří jsou pod vládou císaře Etiopie a země kněze Jana.] — Grosjean, ed. (1977), 80; překlad podle Palomo (2002), 36; Nogueira (2013), 291; Buchon - Tastu (1839), 115.

58 „En sta prouincia sta lo gran anperator presta iohan Senyor de les indies los quals son negres per natura al vuyt an jorn que son nats senyalen los an tres lochs dela cara e batejan los en ayga avsança de roma." [V této provincii vládne velký císař, Kněz Jan, pán Indů, kteří jsou od př́rody černí; osmý den poté, co se narodí, označí je na třech místech obličeje a pokřtí je ve vodě podle římského ritu.] (Kretschmer 1897, 99)

59 Jméno Gutzola či Gozola najdeme na řadě středověkých italských a katalánských map, v Katalánském atlase 1375 označuje celou oblast mezi Atlasem (arabsky Ğibāl al-Ațlas, berbersky/tamazight Idurar $n$ Wațlaș) a Antiatlasem (arabsky al-Ațlas aṣ-șag̀i $\bar{r}$, „malý Atlas“; berbersky/tamazight Adrar Mzziyen) v severním Maroku.
Severní části Asie a Evropy na mapě z Estense, které jsou mimo rozsah Katalánského atlasu, obsahují velmi málo podrobností. Pokud jde o jižní pobřeží Asie, mezi oběma mapami jsou obecně malé rozdíly. Na mapě z Estense je Indický poloostrov méně zřetelný a jižně od něj leží velký ostrov $S a$ lam či Silan (Cejlon či Šrí Lanka). Legenda se zmiňuje o jeho bohatství na rubíny a jiné drahokamy ${ }^{60} \mathrm{~V}$ podstatě jsou však oba nákresy identické. Na východ je ostrov Jáva (Illa Jana), stejně jako v Katalánském atlase. Ostrov Trapobana (rovněž Cejlon!) je rozsáhlejší a je umístěn na jihovýchodní okraj mapy. Okolní oceán (Mar deles indies) zaplňuje množství bezejmenných ostrovů bez jakýchkoli objektů.

Mưže nás překvapit, že mapa $\mathrm{z}$ roku 1450 obsahuje poměrně nejnovější podrobnosti spolu se zastaralými představami v jiných oblastech. Na to existují různě složitá vysvětlení. Např. chybějící podrobnosti a jména v jižních oblastech Afriky se kromě obvyklého konzervatismu mapových děl mohou vysvětlit tím, že kreslír, alespoň pokud jde o Afriku, vynechal všechny podrobnosti, pro něž neměl doklady, aby tak získal místo pro poslední portugalské objevy. Rovněž se můžeme dohadovat, jestli nejjižnější zakreslená část Afriky nepředstavuje určitou povědomost o mysu Dobré naděje.

\section{ZÁVĚREM}

Zásluha katalánských kartografů spočívá ve zkušenosti, s níž využívali nejlepší soudobé prameny, aby modifikovali tradiční obraz světa, přičemž se zřídka pouštěli dále, než za skutečnosti, které byly podloženy fakty. Ve stejném duchu z map odstranili většinu tradičních bajek přijímaných po staletí a dali přednost tomu, že vypustí úplně severní a jižní oblasti (v prŕípadě Katalánského atlasu), nebo ponechají prázdnou jižní Afriku, než aby tyto oblasti zaplnili antropofágy a jinými monstry, jež zdobí tolik středověkých map. Dali rovněž přednost zobrazení historických postav, Mansa Musy (Musse Melly/Musamelli), pána Guineje, jehož pout do Mekky v roce 1324 způsobila senzaci, nebo Holubeima/Olub beina, vládce Tatarů. V tomto duchu kritického realismu katalánští kartografové 14 . a počátku 15 . století se zbavili pout tradice a předjali úspěchy renesance.

60 „Illa de silan en la qual a flums an les quals sa ... te rubins e pedres fines en sia illa a de maranclosas coses." [Ostrov Silan, na němž jsou řeky, kde můžete nalézt rubíny a drahokamy. Na tomto ostrově jsou nádherné věci.] (Kretschmer 1897: 109)

\section{LITERATURA}

Almeida, Manuel Lopes de - Costa Brochado, Idalino Ferreira da - Dias Dinis, António Joaquim, O. F. M., eds. (1963): Monumenta Henricina. Vol. V. Coimbra: Universidade de Coimbra.

Amat di S. Filippo, Petrus (1888): "Recenti Ritrovimenti di Carte Nautiche in Parigi in Londra ed in Firenze," Bollettino della Società geografica italiana, Vol. 25: 268- 
Brunnlechner, G. (2013): "The so-called Genoese World Map of 1457: A Stepping Stone Towards Modern Cartography?", Peregrinations: Journal of Medieval Art \& Architecture, Volume IV, Number 1, 56-80.

Buchon, Jean Alexandre C. (1838): Notice sur un atlas en langue catalane, manuscrit de lan 1374, conservé parmi les manuscrits de la Bibliothèque royale sous le numéro 6816, fonds ancien, in-folio maximo. Par Mm. J. A. C. Buchon. [Paris, Imprimerie royale] 1838. (Extrait des Notices et extraits des manuscrits, Tome XIV, $2^{\mathrm{e}}$ partie.)

Buchon, Jean Alexandre C. - Tastu, Joseph (1839): Notice d'un atlas en langue catalane, manuscrit de l’an 1375, conservé parmi les manuscrits de la Bibliothèque royale sous le numéro 6816, fonds ancien, in-folio maximo. Par Mm. J. A. C. Buchon et J. Tastu. Paris, Imprimerie royale 1839. (Extrait des Notices et extraits des manuscrits, Tome XIV, $2^{\mathrm{e}}$ partie.)

Campbell, Tony (1987): "Portolan Charts from the Late Thirteenth Century to 1500," in: The History of Cartography. Vol. I. Cartography in Prehistoric, Ancient, and Medieval Europe and the Mediterranean, Part 3: Cartography in Medieval Europe and the Mediterranean, edited by J. B. Harley and David Woodward. Chicago \& London: The University of Chicago Press: 371-463. (online: <http://press.uchicago.edu/books/ HOC/HOC_V1/HOC_VOLUME1_chapter19.pdf $>+<$ http://press. uchicago.edu/books/HOC/HOC_V1/HOC_VOLUME1_gallery.pdf> "Portolan charts from the late thirteenth century to 1500. Additions, Corrections, Updates", viz <http://www.maphistory.info/portolanchapter. html >.

Carreras y Candi, Francesch (1919): “Cartografia catalana," Butlleti del Centre Excursionista de Catalunya, XXIX, 1919 (març - juliol), núms. 290-294: 51-74.

Casar, Ma Fuencisla García (2008): "Cielos y aguas bíblicos a la medida del hombre medieval y mediterráneo," Hispania Judaica Bulletin. Articles, Reviews, Bibliography and Manuscripts on Sefarad, Volume 6, 5769/2008: 5-31.

Crone, Gerald Roe [G.R.C.] (1962): “Origin of Early Marine Charts." The Geographical Journal, 128 (1), 114.

Divisament (2006): Le divisament dou monde, in: Polo, Marco, 303-662. [franko-italská redakce]

Edson, Evelyn (2004): "Reviving the crusade: Sanudo's schemes and Vesconte's maps," in: Rosamund Allen (ed.): Eastward Bound: Travel and Travellers, 1050-1550. Manchester University Press, 131-155.

Fleming, Olivia (2012): "Meet the 14th Century African king who was richest man in the world of all time (adjusted for inflation!)," DailyMail (Mail Online), 15 October 2012 <http://www.dailymail.co.uk/news/ article-2218025/Meet-14th-Century-African-king-richest-man-worldtime-adjusted-inflation.html>.

Freitag, Barbara (2013): Hy Brasil: The Metamorphosis of an Island: From Cartographic Error to Celtic Elysium. Amsterdam - New York, NY: Rodopi.

Grosjean, Georges, ed. (1977): Mapamundi, der Katalanische Weltatlas vom Jahre 1375. Herausgegeben und Kommentiert von Georges Grosjean. Dietikon-Zürich: Urs Graf Verlag. [faksimile rukopisu Paris, Bibliothèque nationale française, Richelieu Manuscrits Espagnol 30]

Kennedy, Rebecca Futo - Jones-Lewis, Molly, eds. (2016): The Routledge Handbook of Identity and the Environment in the Classical and Medieval Worlds. Abingdon-on-Thames: Routledge (Routledge Handbooks).

Kogman-Appel, Katrin (2014): "Elisha ben Abraham, Known as Cresques: Scribe, Illuminator, and Mapmaker in Fourteenth-Century Mallorca," in: Ars Judaica, 10, 27-36.

Kogman-Appel, Katrin (2015): "The Scholarly Interests of a Scribe and Mapmaker in Fourteenth-Century Majorca: Elisha ben Abraham Bevenisti Cresques's Bookcase," in: Barco, Javier del, ed. (2015). The Late Medieval Hebrew Book in the Western Mediterranean: Hebrew Manuscripts and Incunabula in Context. Leiden - Boston: Brill, 148-181.

Kretschmer, Konrad (1897): "Die katalanische Weltkarte der Biblioteca Estense zu Modena," Zeitschrift der Gesellschaft für Erdkunde zu Berlin 32 (1897), 65-111 a 191-218.

Kunstmann, Friedrich (1855): "Studien über Marino Sanudo den alteren, mit einem Anhange seiner ungedruckten Briefe," in: Abhandlungen der historisch. Classe der Königl. Bayerisch. Akademie der Wissenschaften. Vol. 7. München, 695-819.

Licata, Alfonso (2012): Lanzarotto Malocello dall'Italia alle Canarie. Prefazioni di Franco Cardini e Francesco Surdich. Roma: CISM, Commissione italiana storia militare, Ministero della difesa.
Llompart i Moragues, Gabriel - Pujades i Bataller, Ramon Josep - Samsó Moya, Julio, eds. (2008): El mon i els dies: L'Atles Català. Barcelona: Enciclopèdia Catalana.

Milano, Ernesto, ed. (1995): Il Mappamondo Catalano Estense / Die Katalanische Estense-Weltkarte. Testi e Bibliografie / Text und Bibliographie: Enesto Milano. Trascrizione del testo originale / Transkription des Originaltextes: Annalisa Battini. Dietikon-Zürich: Urs Graf Verlag. [faksimile rukopisu Modena, Biblioteca estense universitaria, C.G.A.1]

Nogueira, Magali Gomes (2013): O Manuscrito Espagnol 30 e a Família do judeu Cresques Abraham. Um estudo sobre as fontes da Cartografia Maiorquina. (Séculos XIII-XIV). Tese apresentada ao Departamento de Geografia da Faculdade de Filosofia, Letras e Ciências Humanas, da Universidade de São Paulo para obtenção do título de Doutor em Geografia Humana. São Paulo: Universidade de São Paulo.

Oldham, Richard D. (1925): "The Portolan Maps of the Rhône Delta: A Contribution to the History of the Sea Charts of the Middle Ages," The Geographical Journal, 65 (5), 403-424.

Palomo, Àngel Arana (2002): L’atles català de 1375. Treball de final de carrera. Barcelona: Universitat Oberta de Catalunya (UOC), Humanitats i Filologia, Grup de Recerca Hermeneia, Juny, 2002. Dostupné online: <www. hermeneia.net/exemples/atles_catala/Versió_paper_def.doc $>$.

Pelletier, Monique (1994): "Le portulain d'Angelino Dulcert, 1339 / Der Portolan von Angelino Dulcert 1339," Cartographica Helvetica. Fachzeitschrift für Kartengeschichte, Bd. 9-10, Heft 9, 23-31.

Pollard, Elizabeth - Rosenberg, Clifford - Tignor, Robert (2015): Worlds Together, Worlds Apart. A History of the World: From the Beginnings of Humankind to the Present. New York: W. W. Norton \& Company, Inc.

Polo, Marco (2003): Milione. Versione toscana del Trecento. Edizione critica a cura di Valeria Bertolucci Pizzorusso. Indice ragionato di Giorgio R. Cardona. III edizione. Milano: Adelphi Edizioni S.p.A. (gli Adelphi), 174.

Polo, Marco (2006): Milione. Le divisament dou monde. Il Milione nelle redazioni toscana e franco-italiana. A cura di Gabriella Ronchi. Introduzione di Cesare Segre. Milano: Arnoldo Mondadori Editore S.p.A. (I Meridiani Collezione).

Pujades i Bataller, Ramon Josep (2007): Les cartes portolanes: la representació medieval d'una mar solcada. Barcelona: Institut Cartogràfic de Catalunya, l'Institut d'Estudis Catalans i l'Institut Europeu de la Mediterrània.

Rabinowicz, H. (1966): "The Sassoon Treasures," The Jewish Quarterly Review, Vol. 57, No. 2 (Oct., 1966), 136-153.

Riera i Sans, Jaume (1975): "Cresques Abraham, jeue de Mallorca, mestre de mapamundis i de bruíxolas," in: L'Atlas català de Cresques Abraham. (Edición facsímil). Barcelona: Diàfora S.A., 14-22.

Schmieder, Felicitas (2012): "Anspruch auf christliche Weltherrschaft. Die Velletri/Borgia-Karte (15. Jahrhundert) in ihrem ideengeschichtlichen und politischen Kontext," in: Ingrid Baumgärtner - Martina Stercken (Hg.). Herrschaft verorten. Politische Kartographie im Mittelalter und in der frühen Neuzeit. Zürich: Chronos Verlag, 253-272.

\section{AUTOR}

Liščák, Vladimír (9. února 1954), český sinolog. Vědecký pracovník Orientálního ústavu Akademie věd České republiky, v. v. i. Zabývá se zejména styky mezi středověkou Evropou a mongolskou východní Asií (13.-14. století) a dějinami katolických misií v Číně. Je autorem řady článků v češtině, angličtině a několika knih, např. Č́na Dobrodružství Hedvábné cesty (2000), Dějiny Číny, Taiwanu a Tibetu $v$ datech (2008), Konfuciánství od počátkư do současnosti. Dějiny pojmy - osobnosti (2013), Po stopách bratra Odorika. Styky Evropy a mongolské Číny ve 13. a 14. století (s př́lohou Biblioteca Odoriciana) (2014), Františkánské misie v Čínè (13.-18. stoletî) (2015). V roce 2016 získal desetiměsíční stipendium MOFA Taiwan Fellowship s projektem Odoric of Pordenone's Itinerarium and Mongolian China in the fourteenth century.

Kontakt: PhDr. Vladimír Liščák, CSc. Oddělení východní Asie, Orientální ústav Akademie věd České republiky, Pod Vodárenskou věží 4, 18208 Praha 8, e-mail: vliscak@orient.cas.cz 